\title{
Subtype-Selective Fluorescent Ligands as Pharmacological Research Tools for the Human Adenosine $A_{2 A}$ Receptor
}

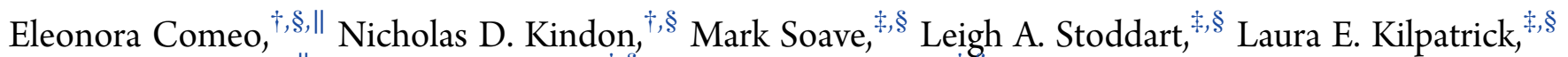

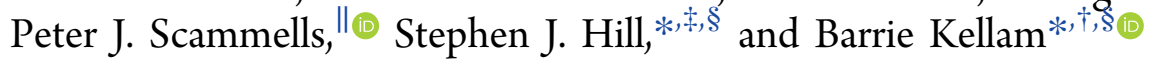

${ }^{\dagger}$ Division of Biomolecular Sciences and Medicinal Chemistry, School of Pharmacy, Centre for Biomolecular Sciences, University of Nottingham, Nottingham NG7 2RD, U.K.

${ }^{\ddagger}$ Division of Physiology, Pharmacology and Neuroscience, School of Life Sciences, University of Nottingham, Nottingham NG7 2UH, U.K.

${ }^{\S}$ Centre of Membrane Proteins and Receptors (COMPARE), University of Birmingham and University of Nottingham, The Midlands NG7 2UH, U.K.

"Medicinal Chemistry, Monash Institute of Pharmaceutical Sciences, Monash University, 381 Royal Parade, Parkville, Victoria 3052 Australia

\section{Supporting Information}

ABSTRACT: Among class A $G$ protein-coupled receptors (GPCR), the human adenosine $A_{2 A}$ receptor $\left(h A_{2 A} A R\right)$ remains an attractive drug target. However, translation of $\mathrm{A}_{2 \mathrm{~A}} \mathrm{AR}$ ligands into the clinic has proved challenging and an improved understanding of $\mathrm{A}_{2 \mathrm{~A}} \mathrm{AR}$ pharmacology could promote development of more efficacious therapies. Subtype-selective fluorescent probes would allow detailed realtime pharmacological investigations both in vitro and in vivo. In the present study, two families of fluorescent probes were designed around the known $\mathrm{hA}_{2 \mathrm{~A}} \mathrm{AR}$ selective antagonist preladenant ( $\mathrm{SCH}$ 420814). Both families of fluorescent antagonists retained affinity at the $\mathrm{hA}_{2 \mathrm{~A}} \mathrm{AR}$, selectivity over all other adenosine receptor subtypes and allowed clear visualization of specific receptor localization through confocal imaging. Furthermore, the Alexa Fluor 647-labeled conjugate allowed measurement of ligand binding affinities of unlabeled $\mathrm{hA}_{2 \mathrm{~A}} \mathrm{AR}$ antagonists using a bioluminescence resonance energy transfer (NanoBRET) assay. The fluorescent ligands developed here can therefore be applied to a range of fluorescence-based techniques to further interrogate $\mathrm{hA}_{2 \mathrm{~A}} \mathrm{AR}$ pharmacology and signaling.

\section{INTRODUCTION}

The adenosine receptors belong to class A of the G proteincoupled receptor (GPCR) superfamily with the latter accounting for about $30 \%$ of the molecular targets for currently marketed drugs. ${ }^{1}$ The pharmacological profile of the adenosine receptors is defined by the function of four adenosine receptor subtypes, $A_{1}, A_{2 A}, A_{2 B}$, and $A_{3}$, each of which possess distinct signaling and pharmacological properties. ${ }^{2}$ Among this family, the adenosine $A_{2 A}$ receptor $\left(A_{2 A} A R\right)$ represents an attractive drug target which has been the subject of intensive medicinal chemistry research over the last 40 years. ${ }^{3,4}$ The $\mathrm{A}_{2 \mathrm{~A}} \mathrm{ARs}$ signal primarily through $\mathrm{G} \alpha_{\mathrm{S}}$ proteins in the periphery ${ }^{2}$ but can also signal through $\mathrm{G} \alpha_{\text {olf }}$ in the striatum. ${ }^{5}$ Upon receptor activation, both $G_{s}$ and $G_{\text {olf }}$-coupled receptors act by stimulating adenylyl cyclase leading to an increase of intracellular cAMP levels and subsequent activation of a series of downstream signaling cascades. ${ }^{6}$ Over $30 \mathrm{X}$-ray crystal structures for the $\mathrm{hA}_{2 \mathrm{~A}} \mathrm{AR}$ have been solved in complex with a range of molecules, providing useful insights into the structural framework of this membrane protein and helped the rational design and development of selective $\mathrm{hA} \mathrm{A}_{\mathrm{A}} \mathrm{AR}$ ligands ${ }^{7-11}$ for the treatment of several diseases including cardiovascular, inflammatory, and CNS disorders. ${ }^{12-14}$ More recently, blockade of the $\mathrm{A}_{2 \mathrm{~A}} \mathrm{AR}$ pathway has generated renewed interest because of the role of adenosinergic signaling in cancer immunotherapy. ${ }^{15}$ In vitro studies and animal models have shown that adenosinemediated activation of the high affinity $\mathrm{A}_{2 \mathrm{~A}} \mathrm{ARs}$ expressed on the surface of immune cells suppresses the antitumor response in the host, facilitating cancer growth and dissemination. ${ }^{16,17}$ Moreover, the expression of $\mathrm{A}_{2 \mathrm{~A}} \mathrm{ARs}$ correlates with the malignancy of the tumor, suggesting these membrane-bound proteins might be considered as a prognostic biomarker for the severity of neoplastic disease. ${ }^{18} \mathrm{~A}$ number of small-molecule $\mathrm{A}_{2 \mathrm{~A}} \mathrm{AR}$ antagonists are currently being explored as novel

Special Issue: Women in Medicinal Chemistry

Received: November 8, 2019

Published: December 30, 2019 
therapeutics to inhibit this adenosine-mediated suppression of the immune responses in patients with solid malignancies, including nonsmall cell lung cancer, breast cancer, and prostate carcinoma (Figure 1).<smiles>Cc1cc(-c2nnc(N)nc2-c2ccc(F)cc2)cc(Cl)n1</smiles><smiles>Cc1ccc(-c2nc(N)nc3c2nnn3Cc2cccc(COC3CCOC3)n2)o1</smiles><smiles></smiles><smiles>Nc1nc(-n2cccn2)nc(-n2cccn2)c1Br</smiles>

Figure 1. Small molecule $\mathrm{hA}_{2 \mathrm{~A}} \mathrm{AR}$ antagonists currently investigated as single agents, or in combination with monoclonal antibodies, in patients with solid tumors.

To date only two molecules targeting the $\mathrm{A}_{2 \mathrm{~A}} \mathrm{AR}$ have reached the market: Regadenoson (Lexiscan, Astellas Pharma), a pharmacological stress agent for myocardial perfusion injury $^{12,19}$ and Istradefylline (NOURIANZ, Kyowa Kirin Inc.), a xanthine-based $\mathrm{hA}_{2 \mathrm{~A}} \mathrm{AR}$ antagonist which has reached the market in Japan for treating the symptoms of Parkinson's disease $(\mathrm{PD})^{20,21}$ However, despite the many therapeutic opportunities associated with the $\mathrm{A}_{2 \mathrm{~A}} \mathrm{AR}$, translation of adenosine ligands from the bench into the clinic has been hampered by a lack of understanding of the tissue and cell-type specific receptor pharmacology, leading to on-target side effects. ${ }^{13}$ Additional knowledge on the function of the $\mathrm{A}_{2 \mathrm{~A}} \mathrm{AR}$ could be achieved through real-time monitoring of the localization and function of the receptor at native expression levels in specific human cell types in both health and disease, with the aim of developing more selective and efficacious therapies. Fluorescent ligands therefore represent useful tools to achieve this aim as they offer the ability to study the target receptor at endogenous expression levels, in real-time and, importantly, in unmodified living cells. ${ }^{22}$

Fluorescent ligands for the ARs have been successfully developed and have allowed various aspects of their pharmacology, such as the signaling ${ }^{23,24}$ and dynamics, ${ }^{25,26}$ to be investigated. For example, the BODIPY 630/650-Xlabeled xanthine amine congener (XAC), developed in our laboratories, allowed the quantification of specific $A_{1} A R-$ antagonist complexes at the single molecule level in living cells using fluorescence correlation spectroscopy (FCS). ${ }^{26}$ However, intracellular accumulation of the ligand observed over extended incubation times through confocal microscopy, as well as the promiscuous nature of the probe in binding other adenosine receptors, restricted its use to recombinant cells. Receptor-subtype selectivity is particularly important when probing the $\mathrm{A}_{2 \mathrm{~A}} \mathrm{AR}$ pharmacology in unmodified, endogenously expressing tissues and cells, as other adenosine receptor subtypes are often coexpressed. ${ }^{2,12}$ Jacobson and co-workers pioneered the development of fluorescent probes selective for the $\mathrm{hA}_{2 \mathrm{~A}} \mathrm{AR}$, including fluorescent analogues of the $\mathrm{A}_{2 \mathrm{~A}} \mathrm{AR}$ selective antagonist SCH442416 labeled with an Alexa Fluor 488 dye, that have been used successfully for fluorescence polarization $^{27}$ and flow cytometry ${ }^{28}$ assays. However, the utility of these probes for bioimaging studies has not yet been reported. This suggests there still remains the need to develop additional selective $h A_{2 A} A R$ probes, optimized for imaging studies that would allow specific visualization of the $\mathrm{hA}_{2 \mathrm{~A}} \mathrm{AR}$ at the single cell level in healthy and diseased systems.

In the present study, we sought to expand the current pharmacological toolkit for the $\mathrm{hA}_{2 \mathrm{~A}} \mathrm{AR}$ by generating a more

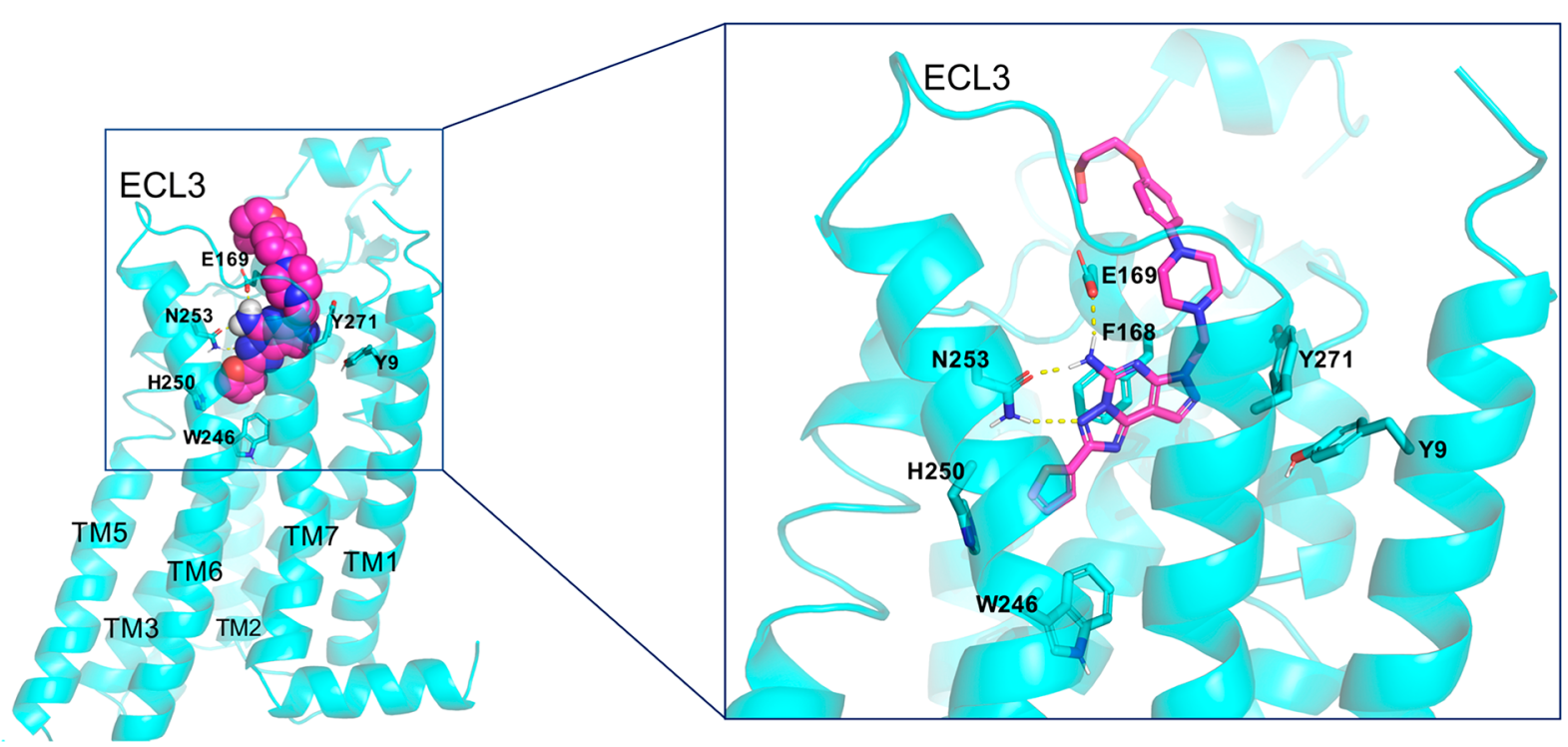

Figure 2. Molecular docking of preladenant to the crystal structure of the $\mathrm{hA}_{2 \mathrm{a}} \mathrm{AR}$ (PDB 4EIY) executed with Schrödinger's Glide (Schrödinger release 2018-3). The images were generated with PyMOL (version 2.2.0). Preladenant is shown in spheres colored magenta. The GPCR is shown in ribbon colored cyan. The key residues are labeled and shown in sticks. A zoomed view of preladenant (shown in licorice) in the binding pocket is depicted in the box with hydrogen bonding interactions depicted as dashed lines. 
Scheme 1. Synthesis of the Fluorescent $h \mathrm{~A}_{2 \mathrm{~A}}$ AR Antagonists ${ }^{a}$
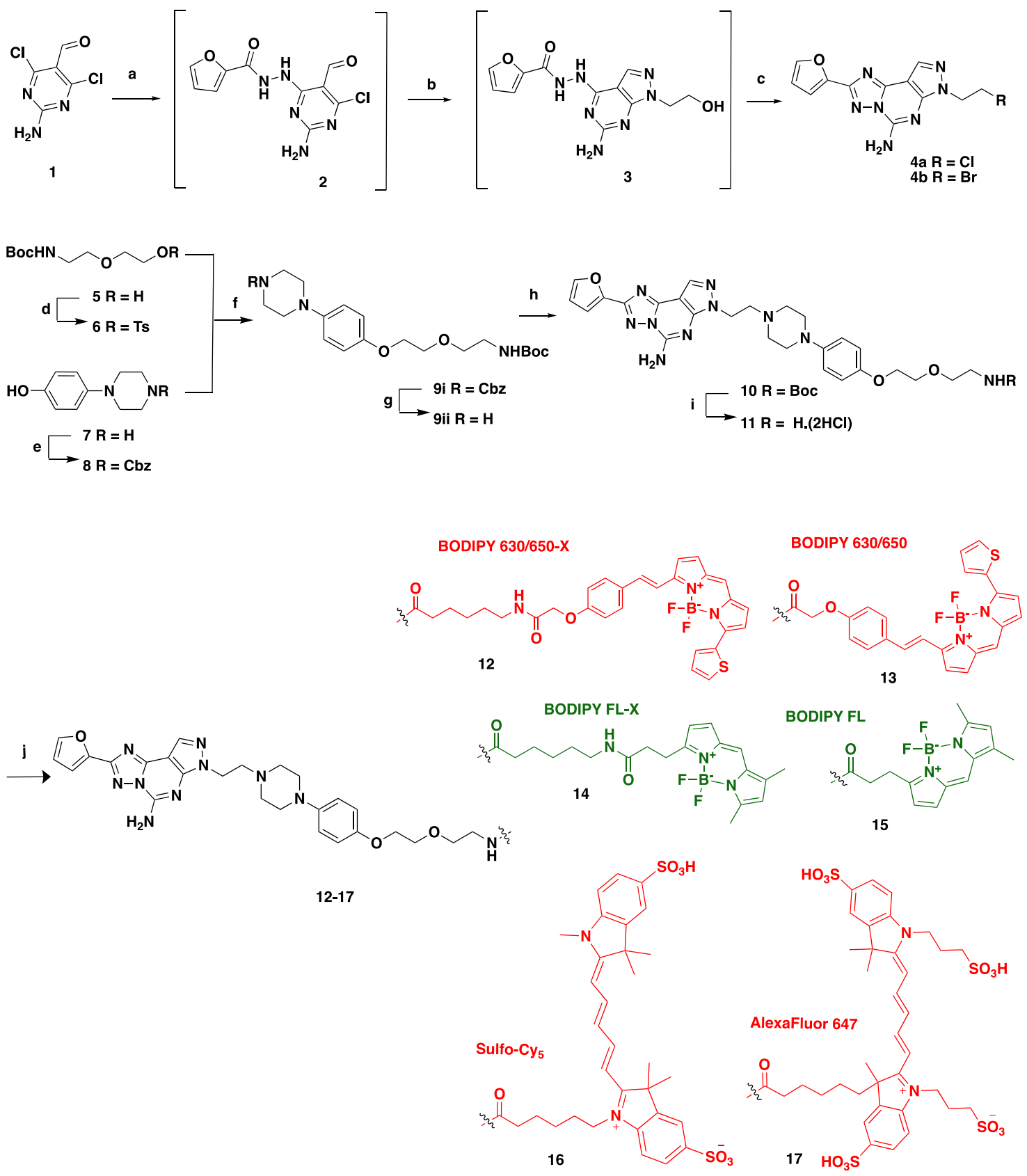

${ }^{a}$ Reagents and conditions: (a) 2-furoic hydrazide, $\mathrm{NEt}_{3}$, dry THF, reflux; (b) 2-hydroxyethylhydrazine, $\mathrm{CH}_{3} \mathrm{CN} / \mathrm{H}_{2} \mathrm{O}$, reflux; (c) $\mathrm{POCl}_{3}, \mathrm{ZnBr}_{2}$, $80^{\circ} \mathrm{C}$ for $5 \mathrm{~h}, 11 \%$ over three steps; (d) TsCl, DIPEA, DMAP 5\%mol, DCM, 86\%; (e) CbzCl, $\mathrm{K}_{2} \mathrm{CO}_{3}, \mathrm{DMF}, 66 \%$; (f) $\mathrm{K}_{2} \mathrm{CO}_{3}, \mathrm{CH}_{3} \mathrm{CN}_{1}, 100{ }^{\circ} \mathrm{C}$ for $6 \mathrm{~h}, 40 \%$ (g) $\mathrm{H}_{2}$, Pd/C, EtOH, 82\%; (h) 4, DIPEA, DMF, $80{ }^{\circ} \mathrm{C}, 20 \%$ (i) $4 \mathrm{~N} \mathrm{HCl}$ in dioxane, RT, quantitative; (j) 12-14-15-16-17 fluorophoreNHS, DIPEA, DMF, RT,97\%, quantitative; 13 BODIPY carboxylic acid, HATU, DIPEA, DMF, 96\%.

versatile suite of fluorescent probes with regard to their photochemical and physicochemical properties and areas of potential application. Here, we report the design, synthesis, and pharmacological evaluation of a novel series of subtypeselective fluorescent ligands $(12-17)$ for the human adenosine $\mathrm{hA}_{2 \mathrm{~A}} \mathrm{AR}$ receptor based upon preladenant (a high affinity $\left(\mathrm{hA}_{2 \mathrm{~A}} \mathrm{AR} K_{\mathrm{i}}=1.0 \mathrm{nM}\right)^{29}$ and highly selective $\left(\mathrm{hA}, \mathrm{hA}_{2 \mathrm{~B}}\right.$ and $\left.\mathrm{hA}_{3} K_{\mathrm{i}}>1000 \mathrm{nM}\right)^{29} \mathrm{hA}_{2 \mathrm{~A}} \mathrm{AR}$ antagonist), which are amenable to use in a variety of fluorescence-based techniques. These $\mathrm{A}_{2 \mathrm{~A}} \mathrm{AR}$ selective fluorescent ligands will be valuable tools for the wider scientific community for both in vitro and in vivo applications and high-resolution imaging studies into the role of $\mathrm{A}_{2 \mathrm{~A}} \mathrm{AR}$ in health and disease.

\section{RESULTS AND DISCUSSION}

Design Strategy. Our synthetic strategy commenced by exploring the existing structure-activity relationships $(\mathrm{SAR})^{4,38-32}$ of the selected parent drug preladenant in binding to the $A_{2 A} A R$ to identify the optimal position of the molecule that would be relatively insensitive to structural modifications and allow fluorophore attachment without affecting the original pharmacological properties of the ligand. This preliminary screening was complemented through in 
silico studies which were undertaken to rationalize the possible binding interactions established between the parent ligand and the $\mathrm{hA}_{2 \mathrm{~A}} \mathrm{AR}$ (Figure 2).

Molecular docking simulations of preladenant to the $1.8 \AA$ resolution crystal structure (PDB 4EIY) of the $\mathrm{hA}_{2 \mathrm{~A}} \mathrm{AR}^{9}$ revealed the core pyrazolo $[4,3-e][1,2,3]$ triazolo $[1,5-c]$ pyrimidin-5-amine (PTP) scaffold interacts with key receptor residues in an equivalent fashion to the antagonist ZM241385, including polar contacts with Asn253 and Glu169 and a $\pi$ stacking interaction with Phe168., The side chain of preladenant adopted a conformation extending toward extracellular loop 3 (ECL3) and, therefore, to a more solvent-exposed region of the GPCR. These results were further validated by previously reported SAR studies, which showed that modifications at the extended methoxyethyl ether moiety were well tolerated. , $30,31,33$ Thus, it seemed logical to exploit this side chain of preladenant as a flexible point to explore linker/fluorophore elaboration. We hypothesized that an amino alkyl spacer would provide sufficient spatial separation between the fluorophore and the orthosteric binding moiety. When designing fluorescent probes the introduction of a spacer between the parent pharmacophore and the fluorophore is often included in the design strategy and the nature and the length of the linker, and the fluorophore itself can significantly influence the final pharmacological profile of the fluorescent conjugate. ${ }^{34,35}$ Structural modifications must be performed at specific positions, which can be easily tolerated and do not cause significant impact upon pharmacological activity. Therefore, we undertook modification of the methoxy tail of the parent compound preladenant by conjugation with an amino alkyl spacer, leading to the corresponding amino functionalized congener amenable to conjugation with a series of commercially available fluorophores (Scheme 1). This novel series of fluorescent ligands included probes featuring the 4,4difluoro-4-bora-3a,4a-diaza-s-indacene (BODIPY) dyes alongside water-soluble dyes such as sulfonated cyanine-5 (sulfoCy5) and Alexa Fluor 647 fluorophores. These probes were selected on the basis of several considerations. For example, the use of fluorophores with long-wavelength excitation/ emission spectra is preferred as it minimizes the degree of overlap with background autofluorescence in living cells. $^{23,35-38}$ The BODIPY fluorophores embody the first choice for fluorescent derivatization given their stability and photochemical properties. ${ }^{39}$ The 6-((4,4-difluoro-5-(2-thienyl)-4-bora-3a,4a-diaza-s-indacene-3-yl)styryloxy)acetyl)aminohexanoic acid (BODIPY630/650) is often the favored among this family of dyes due to its advantageous spectral profile (excitation $630 \mathrm{~nm}$, emission $650 \mathrm{~nm}$ ). It has been previously suggested that given the lipophilic nature of the probe, the BODIPY moiety is likely to reside within the membrane bilayer. Indeed, this fluorophore has been shown to be heavily quenched in aqueous solution, therefore the optimal location would be in a lipid environment as this reduces background fluorescence from nonbound ligand, which is particularly advantageous for imaging studies. ${ }^{34}$ However, the intrinsic lipophilic nature of these dyes may limit their applicability in vivo due to the reduced stability in the bloodstream as well as limited detection after IV administration. ${ }^{40}$ One possible strategy to overcome these issues is by employing water-soluble fluorophores such as those belonging to the Cy5 and Alexa Fluor families of dyes. These watersoluble dyes also possess good photochemical properties and have therefore been particularly advantageous for the development of in vivo probes such as in cancer imaging. ${ }^{41}$

Synthesis of the Fluorescent $h A_{2 A} A R$ Antagonists. On the basis of the information obtained from the molecular docking studies, a novel series of fluorescent antagonists for the $\mathrm{hA}_{2 \mathrm{~A}} \mathrm{AR}$ receptor were synthesized featuring BODIPY-, Cy5-, and AF647-based probes. The general route to the desired probes is illustrated in Scheme 1.

The synthesis comprised 10 steps to a common precursor from which six different fluorescent analogues were generated. First, a one-pot procedure reported by Kuo et al. ${ }^{42}$ for the synthesis of intermediate $\mathbf{4}$ was followed. This involved reaction of commercially available 2-amino-4,6-diclhoropyrimidine-5-carbaldehyde (1) with 2-furoic hydrazide in anhydrous THF in the presence of $\mathrm{Et}_{3} \mathrm{~N}$ under reflux for $2 \mathrm{~h}$ to obtain 2 via nucleophilic aromatic substitution $\left(S_{N} A r\right)$. Once the desired product was formed, solvent was removed in vacuo and a solution of 2-hydroxyethylhydrazine in a mixture of $\mathrm{CH}_{3} \mathrm{CN} / \mathrm{H}_{2} \mathrm{O}$ was added to the crude product to displace the chlorine at the 2-position through $S_{N} A r$ and afforded compound 3 after ring rearrangement. Thereafter, 3 was cyclized in the presence of a catalytic amount of $\mathrm{ZnBr}_{2}$ and an excess of $\mathrm{POCl}_{3}$.

This dehydrative cyclization occurred with concomitant Dimroth rearrangement ${ }^{43,44}$ to afford intermediate $\mathbf{4}$ in a disappointing overall yield ( $11 \%$ over three steps). Mass spectroscopy and ${ }^{1} \mathrm{H}$ NMR showed that the desired product afforded was a 2:1 mixture of chloride and bromide derivatives: one single peak at $t_{R}=2.50, \mathrm{M}+\mathrm{H}^{+}=304\left(4_{\mathrm{a}}\right)$ and $\mathrm{M}+\mathrm{H}^{+}=$ $348\left(4_{b}\right)$; in the ${ }^{1} \mathrm{H}$ NMR analysis the peaks characteristic of the aromatic region of the spectra were in common to both. Conversely, the peaks characteristic of the alkyl halide tail appeared in the spectra with different chemical shifts for both bromide and chloride derivatives: peaks at $4.66 \mathrm{ppm}(\mathrm{t}, J=6.2$ $\left.\mathrm{Hz}, 1 \mathrm{H},-\mathrm{CH}_{2} \mathrm{Br}\right), 4.60 \mathrm{ppm}\left(\mathrm{t}, J=5.9 \mathrm{~Hz}, 2 \mathrm{H},-\mathrm{CH}_{2} \mathrm{Cl}\right)$, $4.09 \mathrm{ppm}\left(\mathrm{t}, J=5.9 \mathrm{~Hz}, 2 \mathrm{H},-\mathrm{CH}_{2} \mathrm{CH}_{2} \mathrm{Cl}\right), 3.94 \mathrm{ppm}(\mathrm{t}, J=$ $\left.6.2 \mathrm{~Hz}, 1 \mathrm{H},-\mathrm{C}_{2} \mathrm{CH}_{2} \mathrm{Br}\right)$.

Subsequently, synthesis of the amino functionalized tail of the final molecule started by activating the hydroxyl group of commercially available $\mathbf{5}$ with tosyl chloride in DCM to afford 6. Under basic conditions, commercially available 1-(4hydroxyphenyl) piperazine 7 was protected at the free secondary amino group with benzyl chloroformate to afford the corresponding benzylcarbamate-protected piperazine derivative 8 with reasonable yield (66\%). Under basic conditions, nucleophilic displacement of the tosyl group of 6 by the phenolic hydroxyl of $\mathbf{8}$ afforded the diprotected intermediate $\mathbf{9}$. This allowed selective removal of the two protecting groups employing different conditions: hydrogenolysis of the benzylcarbamate group in the presence of $10 \%$ palladium-oncarbon $(\mathrm{Pd} / \mathrm{C})$ gave the corresponding free secondary amine in quantitative yield. Under basic conditions, substitution of the primary ethyl halide tail of compound 4 by the nucleophilic piperazine nitrogen afforded compound 10, which underwent acidolytic Boc deprotection to generate the corresponding amine $\mathbf{1 1}$ as its di-HCl salt. Finally, $\mathbf{1 1}$ was coupled with the appropriate commercially available BODIPY, Cy5, and AF647 succinimidyl esters and to a BODIPY 630/650 carboxylic acid (13) synthesized in our laboratory ${ }^{45}$ to afford a focused library of six fluorescent analogues $(12-17)$.

The novel fluorescent conjugates were isolated and purified by reverse-phase high performance liquid chromatography (RP-HPLC). The final purity of the fluorescent ligands was 
confirmed by analytical RP-HPLC with dual wavelength detection and were determined as being $\geq 96 \%$ homogeneous. Additionally, the chemical identity of probes (12-17) was confirmed by high resolution mass spectrometry (HRMS) (TOF ES+ and ES-).

Pharmacological Evaluation of the Fluorescent $h A_{2 A} A R$ Antagonists. The novel preladenant-based fluorescent ligands were assessed in a variety of pharmacological assays. First, the novel compounds were validated through a bioluminescence resonance energy transfer $(\mathrm{BRET})^{46,47}$ ligand binding assay, a proximity assay $(<10 \mathrm{~nm})$ that exploits the energy transfer between the donor bioluminescent protein nanoluciferase (NanoLuc $)^{48}$ tagged to the receptor of interest at its $\mathrm{N}$-terminus (NanoLuc- $\mathrm{A}_{2 \mathrm{~A}} \mathrm{AR}$ ) and an acceptor fluorescent molecule. For all of the fluorescent ligands used in the present study, a clear saturable component of specific binding could be detected (Table 1 and Figure 3 ) to the $\mathrm{hA}_{2 \mathrm{~A}} \mathrm{AR}$ that was associated with low levels of nonspecific binding across all of the concentrations of fluorescent ligands measured.

Table 1. Binding Affinities of the Novel Fluorescent Ligands Determined in Whole HEK293G Cells Transiently Expressing the NanoLuc- $h \mathrm{~A}_{2 \mathrm{~A}} \mathrm{AR}$

\begin{tabular}{lrr}
\multicolumn{1}{c}{ compd } & $\mathrm{p} K_{\mathrm{D}}(\log M)^{a}$ & $n$ \\
$\mathbf{1 2}(\mathrm{BY} 630 / 650-\mathrm{X})$ & $7.39 \pm 0.05$ & 5 \\
$\mathbf{1 3}(\mathrm{BY} 630 / 650)$ & $7.39 \pm 0.02$ & 4 \\
$\mathbf{1 4}(\mathrm{BY}-\mathrm{FL}-\mathrm{X})$ & $7.77 \pm 0.06$ & 4 \\
$\mathbf{1 5}$ (BY-FL) & $7.65 \pm 0.10$ & 5 \\
$\mathbf{1 6}$ (Sulfo-Cy5) & $7.08 \pm 0.09$ & 5 \\
$\mathbf{1 7}$ (AF647) & $7.22 \pm 0.05$ & 5
\end{tabular}

${ }^{a} \mathrm{p} K_{\mathrm{D}}$ value was calculated from the negative logarithm of the equilibrium dissociation constant $\left(K_{\mathrm{D}}\right)$ determined from saturation ligand binding assay using increasing concentration of labeled ligand in the absence or presence (to determine nonspecific binding) of unlabeled ligand preladenant $(1 \mu \mathrm{M})$. Data are expressed as mean \pm SEM of $n$ experiments, where each experiment was performed in triplicate.

The novel fluorescent conjugates were able to bind to the $\mathrm{hA}_{2 \mathrm{~A}} \mathrm{AR}$ with good affinity. However, the affinity values measured for the water-soluble probes were slightly lower than the BODIPY conjugates (Table 1). A possible explanation of the differences in binding affinity values among the two groups of fluorescent ligands could be attributed to the fluorophores employed, considering they constituted the only structural difference between the compounds. It is possible that the boron dipyrromethene scaffold of the BODIPY-labeled $\mathrm{hA}_{2 \mathrm{~A}} \mathrm{AR}$ fluorescent antagonists engages in a cooperative fashion with key residues in an additional pocket of the receptor, ${ }^{28}$ thereby contributing to increase the binding affinity of the ligands. Conversely, due to the more hydrophilic nature of the cyanine5 and AF647-bearing probes, it is possible that these dyes are likely to be extending toward the extracellular medium without engaging to key residues. This hypothesis is consistent with previous work from our laboratories in which it has been demonstrated that the selective $\mathrm{A}_{3}$ fluorescent conjugate bearing a $\mathrm{Cy} 5$ moiety displayed 300 -fold lower affinity compared to the corresponding BODIPY630/650 conjugate with the same pharmacophore and linker, suggesting that the BODIPY fluorophores directly contribute in enhancing the binding affinity of ligands. ${ }^{23,28,35}$
Differences in the BRET ratio observed can be attributed to a variety of factors (Figure 3). For example, when using greenemitting ligands (excitation $503 \mathrm{~nm}$, emission $512 \mathrm{~nm}$ ) a greater contribution from the NanoLuc emission spectra (emission peak $462 \mathrm{~nm}$ ) is detected in the green acceptor emission channel $(535 \mathrm{~nm})$, leading to an increase in the BRET ratio. Conversely, with red-shifted ligands the contribution of the NanoLuc emission is markedly reduced in the red acceptor channel and this leads to a reduction in the background BRET ratio. ${ }^{46}$ The distance and the specific orientation of the acceptor fluorophore with respect to the donor NanoLuc can also influence the efficiency of the energy transfer between the two species and contribute to the absolute differences in the BRET ratio observed. ${ }^{49}$

Achieving $A_{2 A} A R$ selectivity represents one of the major objectives of our study, especially when the fluorescent ligands are being developed with the intention of being applied to a variety of fluorescence-based techniques in different tissues and animal models endogenously expressing other adenosine receptor subtypes. The NanoBRET saturation ligand binding assay allowed us to determine the binding affinity of each fluorescent $\mathrm{A}_{2 \mathrm{~A}} \mathrm{AR}$ antagonist in HEK293 cells stably expressing either the NanoLuc- $A_{1}$, NanoLuc- $A_{2 B}$, or the NanoLuc- $A_{3}$ ARs. The results revealed that no specific binding of the fluorescent ligands was detectable at the $A_{1}, A_{2 B}$, and $\mathrm{A}_{3} \mathrm{AR}$ subtypes at concentrations tested (Figure 4).

Given the higher affinity displayed at the $A_{2 A} A R$, the BODIPY-labeled ligands were selected to assess whether the novel synthesized probes were able to retain the functional antagonistic ability of the parent compound preladenant. This was performed using a previously described CRE-SPAP reporter gene assay ${ }^{50}$ in $\mathrm{CHO}$ cells expressing the human adenosine $\mathrm{hA} \mathrm{A}_{2 \mathrm{~A}} \mathrm{AR}$ receptors. All the BODIPY-labeled ligands were able to inhibit adenosine-5- $N$-ethylcarboxamide (NECA)-mediated increase in SPAP production in a competitive fashion, causing a rightward shift of the NECA response curve as shown in Figure 5. From these data, it was possible to perform Schild regression analysis and estimate the affinity of each compound as shown in Table 2.

The fluorescent ligands largely retained their functional antagonism as compared to the parent compound preladenant. Moreover, when comparing fluorescent ligands bearing a short linker (see Scheme 1), no significant difference in the measured functional affinity was observed $(p>0.05$, comparing compounds 13 and $\mathbf{1 5}$, unpaired $t$ test). Conversely, when comparing fluorescent ligands containing a longer linker the BODIPY 630/650 conferred 20-fold increase in affinity to the congener $(p<0.05$, comparing compounds 12 and 14, unpaired $t$ test). In this pharmacological assessment, compound 12 was the most potent of the series $\left(\mathrm{pA}_{2}=9.31 \pm\right.$ 0.38 , Figure $5 \mathrm{~A}$ and Table 2 ). Interestingly, the affinity values measured via the NanoBRET saturation ligand binding assay (Table 1) were significantly lower compared to the affinity values obtained in CRE-SPAP gene-reporter assay (Table 2). The discrepancy in the affinity values is most likely due to the different host cell type and species (hamster versus human) employed in the two assays (CHO cells for CRE-SPAP and HEK293G cells for NanoBRET), the assay configuration (e.g., the influence of the furimazine substrate for NanoLuc) as well as the influence of the tag used in the NanoBRET experiments (transiently expressed NanoLuc-hA ${ }_{2 \mathrm{~A}} \mathrm{AR}$ for NanoBRET and stably expressed wild-type $\mathrm{hA}_{2 \mathrm{~A}} \mathrm{AR}$ for CRE-SPAP). ${ }^{51}$ However, it is important to note that a small reduction in 
a)

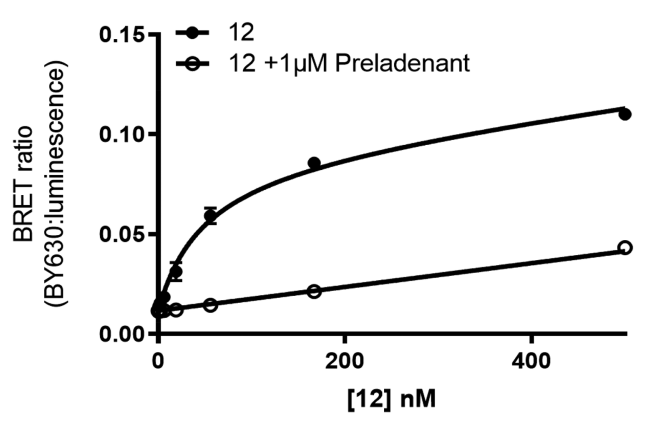

c)

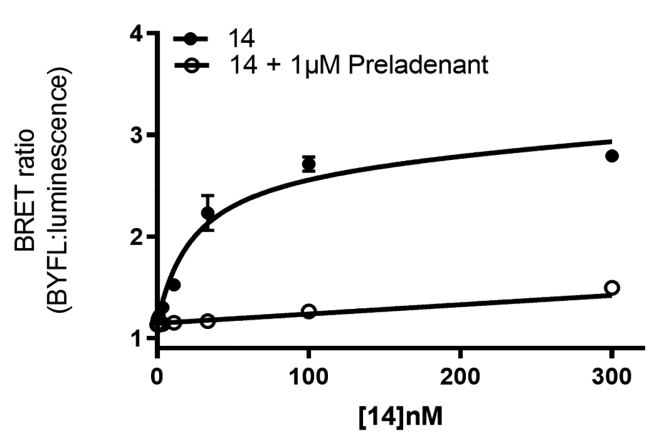

e)

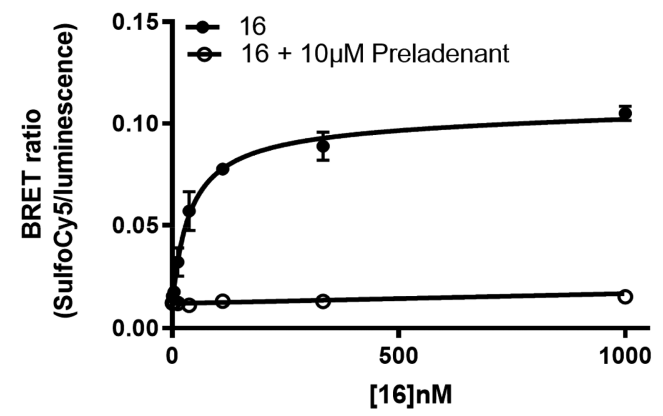

b)

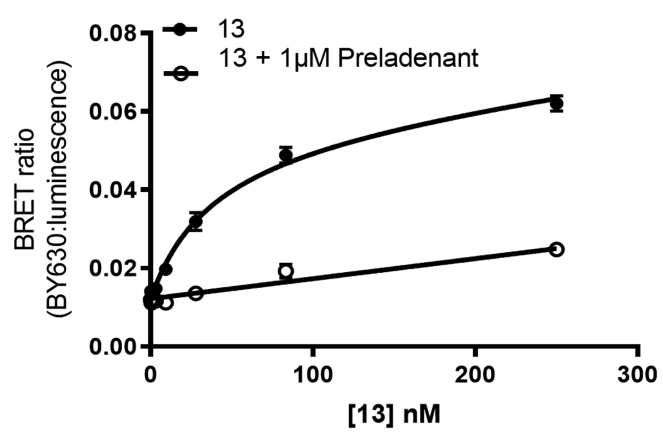

d)

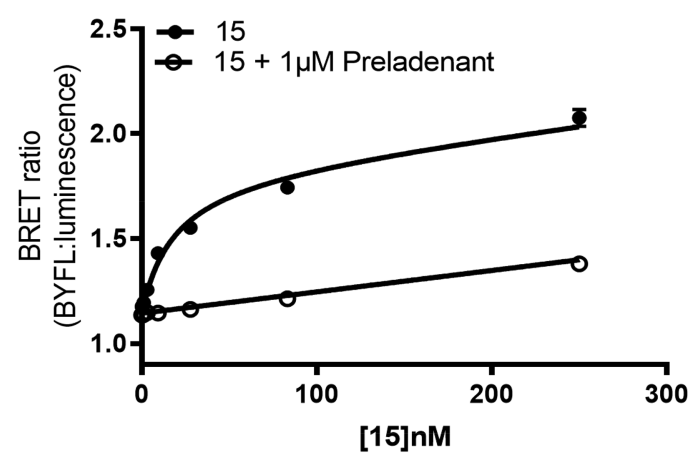

f)

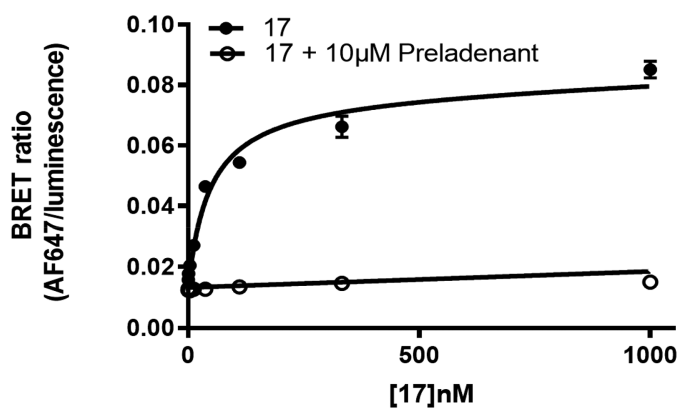

Figure 3. NanoBRET saturation binding curves measured in HEK293G cells transiently expressing the NanoLuc- $h \mathrm{~A}_{2 \mathrm{~A}} \mathrm{AR}$ for (a) 12, (b) 13, (c) 14, (d) 15, (e) 16, and (f) 17 in the presence (open circles) and absence (closed circles) of $1 \mu \mathrm{M}$ preladenant. The graphs depicted are representative of $n=5(\mathrm{a}, \mathrm{d}, \mathrm{e}$, and $\mathrm{f})$ or $n=4(\mathrm{~b}, \mathrm{c})$ separate experiments. Each data point represents the mean value \pm SEM performed in triplicate in a single experiment.

binding affinity of the fluorescent probe is not necessarily detrimental as long as the probe binds to the targeted receptor with sufficient specificity. ${ }^{52}$

Measuring the binding kinetics of a drug candidate is becoming extremely relevant considering the emerging concept that the rates at which a drug binds to its molecular target $\left(k_{\text {on }}\right)$ and dissociates from it $\left(k_{\text {off }}\right)$ may be considered more valuable parameters for predicting the effectiveness of a drug candidate in vivo. ${ }^{53,54}$ In this regard, the BODIPY630/650-X-labeled analogue 12 was selected to be screened for its kinetic profile through a time-resolved fluorescence energy transfer (TR-
FRET $)^{55-58}$ assay in membrane preparations from SNAPtagged-hA ${ }_{2 \mathrm{~A}}$ AR-HEK293 cells (Figure 6). TR-FRET is a methodology which exploits proteins labeled with lanthanides (e.g., terbium) as donor fluorophores. Lanthanides display a long emission lifetime which allows for a time delay of the measurements between the excitation and the fluorescence of the acceptor fluorophore. This increases the sensitivity of the assay due to a reduction of the short-lived background fluorescence. ${ }^{52,55,58}$ The TR-FRET technology allowed us to monitor the binding kinetics of $\mathbf{1 2}$ by measuring the observed association constant $\left(K_{\mathrm{obs}}\right)$ at four different concentrations of 
a)

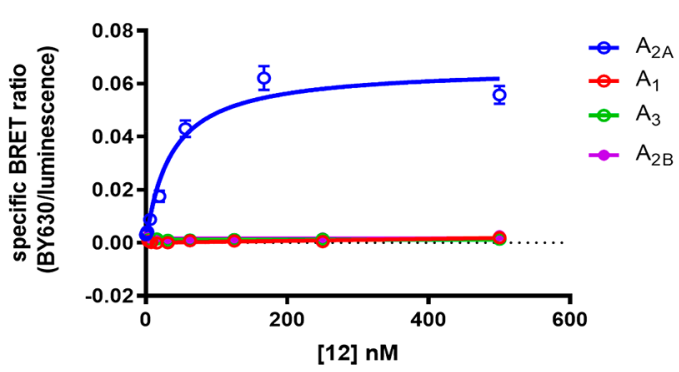

c)

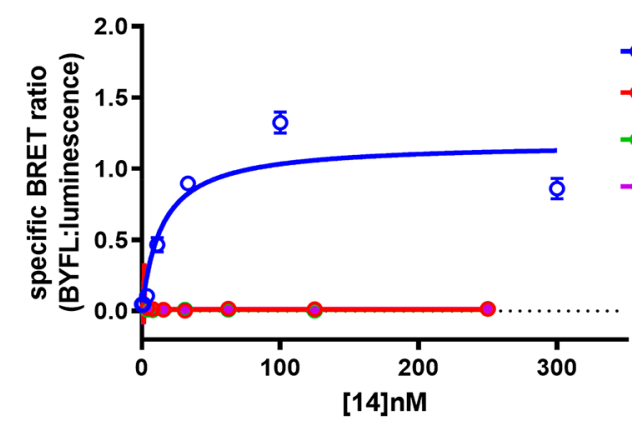

e)

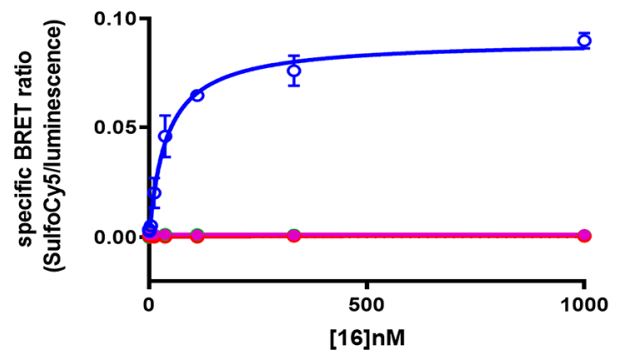

b)

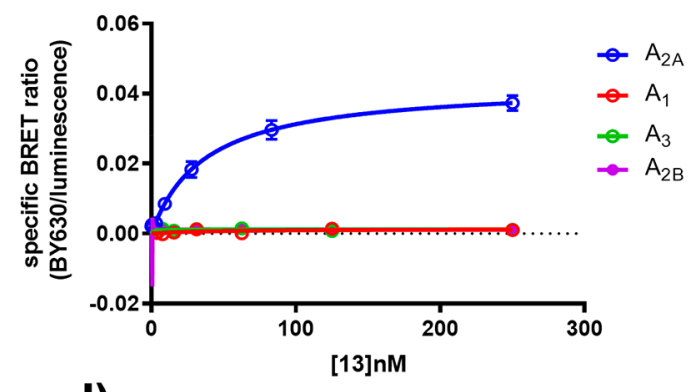

d)
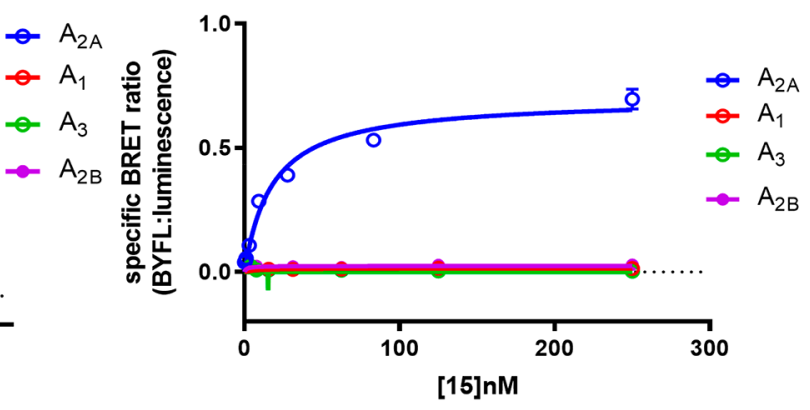

f)
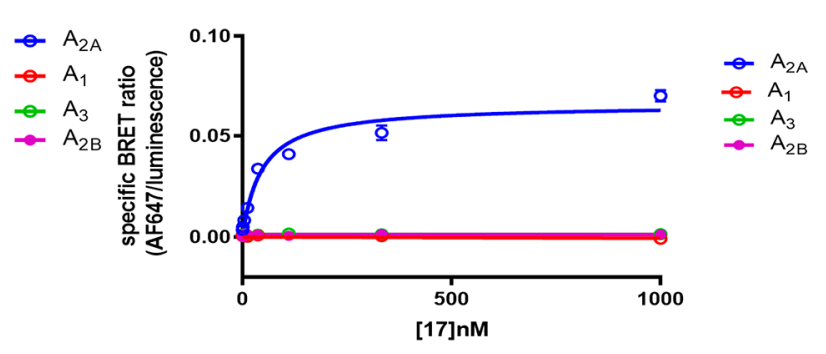

Figure 4. Specific binding of the novel fluorescent ligands at each subtype of adenosine receptor. The selectivity profiling of compound $\mathbf{1 2}$ (a), 13 (b), 14 (c), 15 (d), 16 (e), and 17 (f) is depicted by showing only the specific binding at each adenosine receptor subtype. For each compound, the specific binding at each adenosine receptor was obtained by subtracting the nonspecific binding component from the total binding derived from saturation binding experiments (see Figure 1 and Table 1). Nonspecific binding was defined in the presence of $1 \mu \mathrm{M}$ preladenant for NanoLuc$\mathrm{A}_{2 \mathrm{~A}} \mathrm{AR}, 10 \mu \mathrm{M}$ DPCPX for NanoLuc- $\mathrm{A}_{1}, 10 \mu \mathrm{M}$ MRS1220 for NanoLuc- $\mathrm{A}_{3}$, and $10 \mu \mathrm{M}$ PSB603 for NanoLuc- $\mathrm{A}_{2 \mathrm{~B}}$, respectively. The graphs shown above are representative of $n=4(\mathrm{c}, \mathrm{d})$ and $n=5(\mathrm{a}, \mathrm{b}, \mathrm{e}$, and $\mathrm{f})$ experiments, and the data are mean \pm SEM of triplicate determinations in a single representative experiment.

fluorescent ligand over a period of $1 \mathrm{~h}$. The specific FRET signal was obtained by subtracting the nonspecific signal (determined in the presence of $10 \mu \mathrm{M} \mathrm{ZM} 241385$ ) from the total signal at each time point. The kinetic parameters $k_{\text {on }}=2.4$ $\pm 0.3 \times 10^{6} \mathrm{M}^{-1} \mathrm{~min}^{-1}, k_{\text {off }}=0.029 \pm 0.004 \mathrm{~min}^{-1}, \mathrm{p} K_{\mathrm{D}}=7.91$ \pm 0.06 , and the residence time $\left(1 / k_{\text {off }}\right) \mathrm{Tr}=35.36 \pm 4.11 \mathrm{~min}$, $n=5$ were then calculated by globally fitting the resulting FRET data. This study revealed that fluorescent conjugate $\mathbf{1 2}$ has a relatively rapid on-rate but once bound dissociates slowly. In addition, from the $60 \mathrm{~min}$ time point we were also able to plot an equilibrium saturation curve of $\mathbf{1 2}$ and directly measure the equilibrium dissociation constant $\left(K_{\mathrm{D}}=15.47 \pm 1.92 \mathrm{nM}\right.$, Supporting Information, Figure S2) which was comparable to the value obtained from the kinetic analysis fit.

Interestingly, we found that the binding affinity $\mathrm{p} K_{\mathrm{D}}$ of $\mathbf{1 2}$ measured in this kinetic study $(7.91 \pm 0.06)$ in HEK293G cell membranes was similar to the $\mathrm{p} K_{\mathrm{D}}(7.39 \pm 0.05)$ measured in the same cells in NanoBRET experiments. These data suggest that the large difference in observed binding affinity for $\mathbf{1 2}$ between NanoBRET experiments in HEK293G cells and CRESPAP functional experiments in CHO-K1 cells is largely due to the host cellular environment. Having established that the novel fluorescent probes retain functional activity and binding affinity at the $\mathrm{hA}_{2 \mathrm{~A}} \mathrm{AR}$, we next evaluated their utility for confocal microscope imaging studies. Ideally, the novel fluorescent ligands should bind specifically to the $A_{2 A} A R$ receptors on the cell surface and show both low levels of nonspecific binding and diffusion into the cell cytosol. From the BODIPY-labeled probes, we selected compounds 12 (redemitting) and 15 (green-emitting) (Scheme 1) and determined whether the selected compounds were suitable for visualization of receptors in live cells. To this end, confocal 
a)

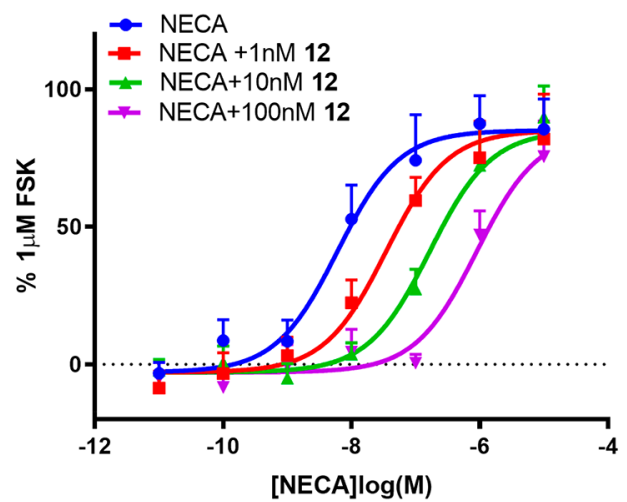

c)

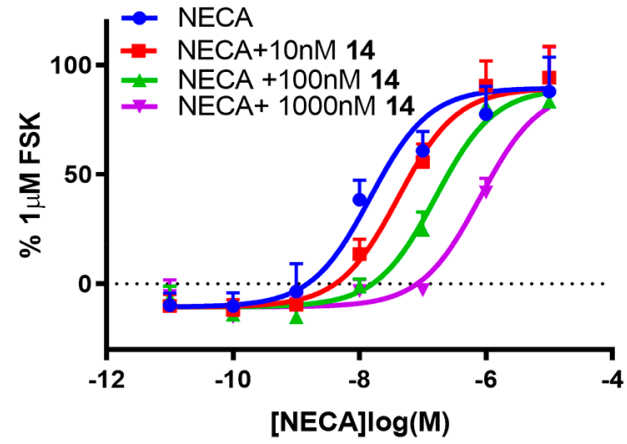

b)

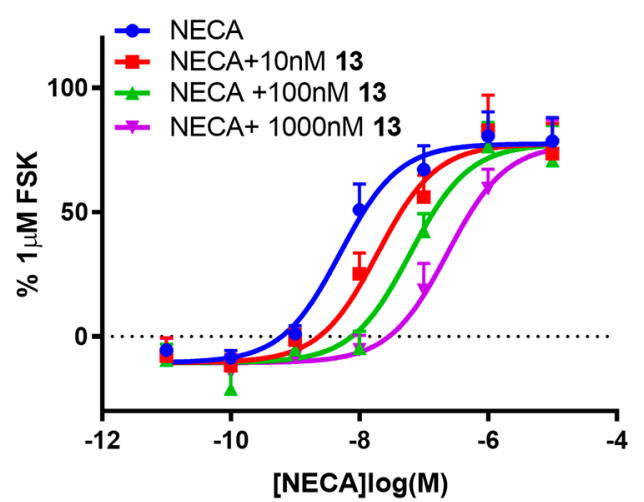

d)

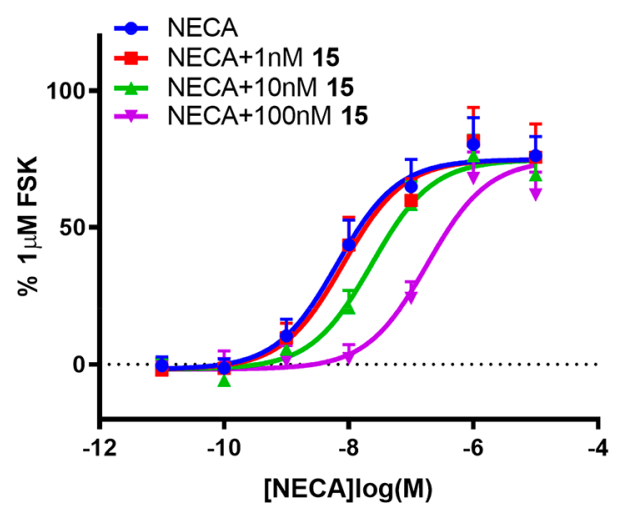

Figure 5. Inhibition of NECA-stimulated SPAP-secretion by the antagonists 12 (a), 13 (b), 14 (c), and 15 (d). CHO CRE-SPAP cells expressing the human $\mathrm{A}_{2 \mathrm{~A}}$ receptor were stimulated with a concentration range of the agonist NECA in the absence and presence of the fluorescent antagonist of interest $(1,10$, and $100 \mathrm{nM}$ for 12 and 15;10, 100, and $1000 \mathrm{nM}$ for 13 and 14). Data have been expressed as a percentage of the SPAP production in response to serum-free media ( $0 \%)$ and to $1 \mu \mathrm{M}$ forskolin (FSK, 100\%). The data shown represent the combined mean \pm SEM of $n$ $=7(\mathrm{a}), n=6(\mathrm{~b}, \mathrm{~d})$ and $n=5(\mathrm{c})$ experiments, where each experiment was performed in triplicate.

Table 2. $\mathrm{pA}_{2}$ Values of the BODIPY-Labeled Fluorescent Ligands

\begin{tabular}{lll}
\multicolumn{1}{c}{ compd } & $h \mathrm{~A}_{2 \mathrm{~A}} \mathrm{AR} \mathrm{pA}_{2}{ }^{a}$ & $n$ \\
$\mathbf{1 2}(\mathrm{BY} 630 / 650-\mathrm{X})$ & $9.31 \pm 0.38^{* \dagger}$ & 7 \\
$\mathbf{1 3}(\mathrm{BY} 630 / 650)$ & $8.61 \pm 0.30$ & 6 \\
$\mathbf{1 4}(\mathrm{BY}-\mathrm{FL}-\mathrm{X})$ & $7.91 \pm 0.26^{*}$ & 5 \\
$\mathbf{1 5}$ (BY-FL) & $8.40 \pm 0.26^{\dagger}$ & 6
\end{tabular}

${ }^{a}$ Affinity of the BODIPY-labeled fluorescent ligands. Ability for these ligands to inhibit the NECA-stimulated CRE-SPAP response in CHO cells expressing the $h \mathrm{~A}_{2 \mathrm{~A}} \mathrm{AR}$. Data are mean \pm SEM for $n$ separate experiments performed in triplicate (statistical significance was defined as $*_{p}<0.05$ unpaired $t$ test comparing 12 and 14. ${ }^{\dagger} p<$ 0.05 unpaired $t$ test comparing the binding affinity of 12 and 15 measured in CRE-SPAP assay and the NanoBRET assay).

microscopy was conducted on HEK293 cells expressing the SNAP-tagged $\mathrm{hA}_{2 \mathrm{~A}} \mathrm{AR}$ (Figure 7). The images captured with the confocal microscope revealed that both compounds 12 and 15 bound specifically to the SNAP-tagged $\mathrm{hA}_{2 \mathrm{~A}} \mathrm{AR}$ shown by the high level of fluorescence localized at the cell membrane. Preincubation with $1 \mu \mathrm{M}$ of unlabeled antagonist ZM241385 produced a significant reduction of the fluorescence intensity and very little intracellular fluorescence was observed. This

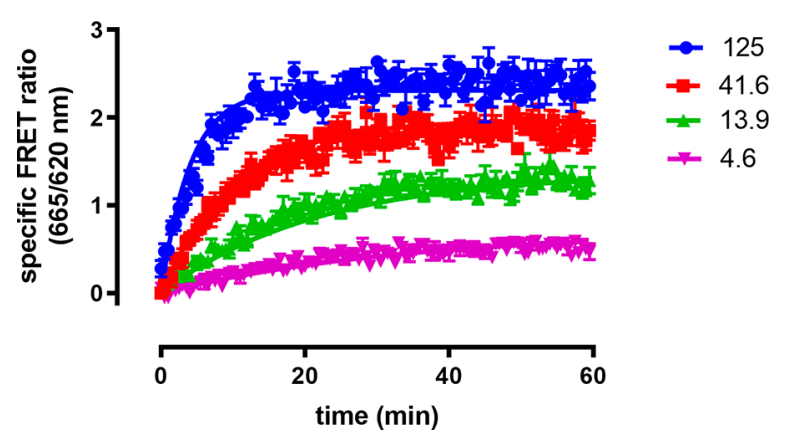

Figure 6. TR-FRET association kinetic curve of specific 12 binding to terbium-labeled SNAP-tagged-hA ${ }_{2 \mathrm{~A}} \mathrm{AR}-\mathrm{HEK} 293$ cell membranes at $37^{\circ} \mathrm{C}$. Cell membranes were treated with the indicated concentration of fluorescent ligand, and the FRET signal was monitored every $30 \mathrm{~s}$ for $1 \mathrm{~h}$. Nonspecific binding was determined in the presence of $10 \mu \mathrm{M}$ ZM241385. The graph presented is a representative of $n=5$ experiments performed in triplicate.

demonstrated that binding of both compounds was specific at the SNAP-tagged $h A_{2 A} A R$ as it was surmounted by high concentration of unlabeled $\mathrm{hA} \mathrm{A}_{2 \mathrm{AR}} \mathrm{Antagonist}$. 

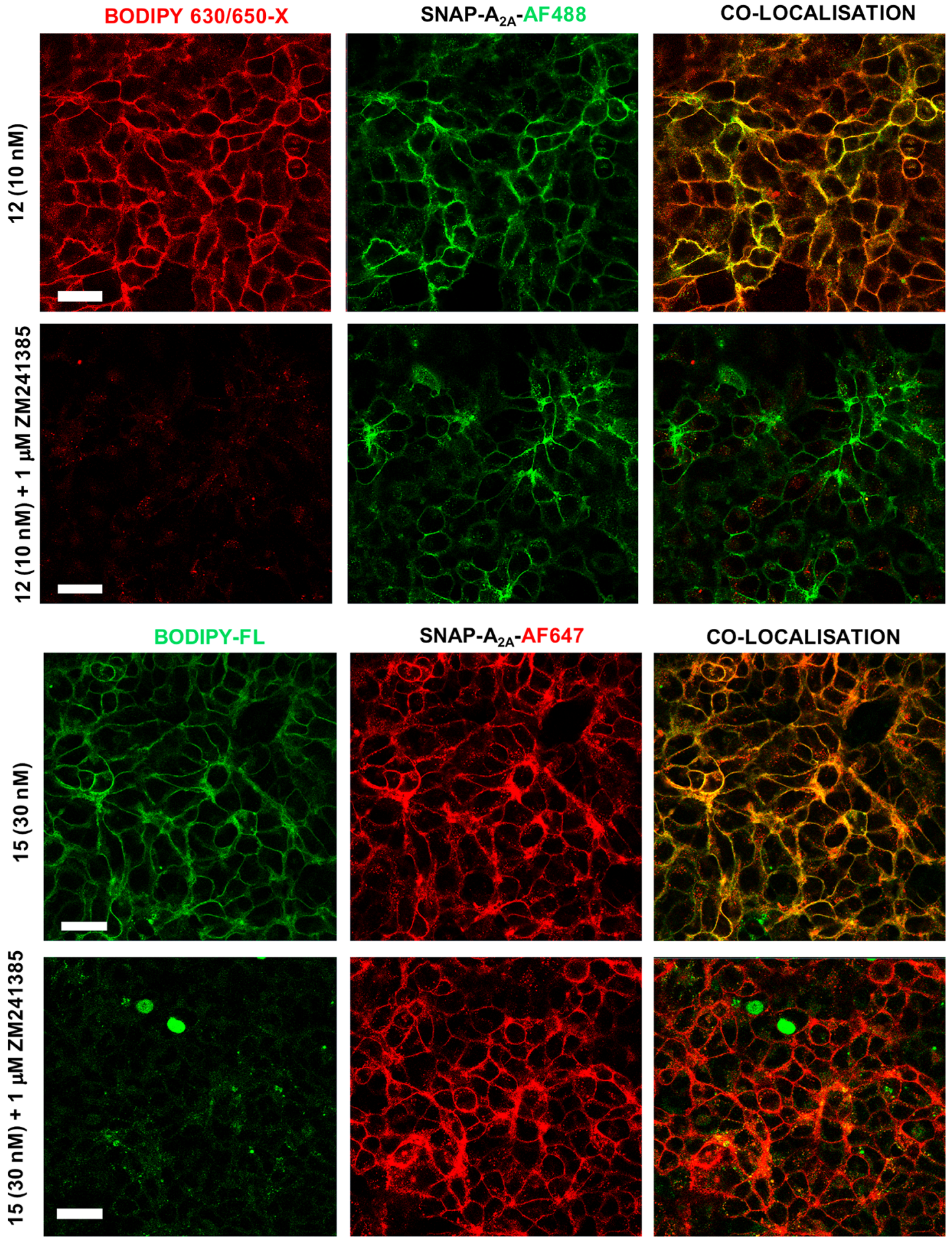

Figure 7. Live cell confocal imaging of $12(10 \mathrm{nM})$ and $15(30 \mathrm{nM})$ binding to SNAP-tagged $h \mathrm{~A}_{2 \mathrm{~A}} \mathrm{AR}$ HEK293 cells in the absence or presence of $1 \mu \mathrm{M}$ of unlabeled antagonist ZM241385. Cells were incubated at $37{ }^{\circ} \mathrm{C}$ with BG-Alexa Fluor 488 when imaging red-shifted ligands (12) or BGAlexa Fluor 647 to label the SNAP-tag on the N-terminus of the receptor when imaging green-shifted ligands (15) (middle frames). Images are representative of images captured in three separate experiments (scale bar: $20 \mu \mathrm{m}$ ).

We also investigated whether the water-soluble $\mathrm{hA}_{2 \mathrm{~A}} \mathrm{AR}$ fluorescent ligands were able to allow receptor visualization through confocal imaging. The results revealed that probes $\mathbf{1 6}$ and $\mathbf{1 7}$ bind to the SNAP-tagged $h \mathrm{~A}_{2 \mathrm{~A}} \mathrm{AR}$ as demonstrated by the high degree of fluorescence observed at the cell membranes (Figure 8). Most importantly, the binding of the two ligands to the $A_{2 \mathrm{~A}} \mathrm{AR}$ was highly specific as preincubation with $1 \mu \mathrm{M}$
ZM241385 completely inhibited the binding of each fluorescent ligand. Very little nonspecific binding was detected, and rewardingly, no measurable uptake of these ligands into in the cytosol could be seen.

Compound 17 was selected for further studies. In particular, the utility of Alexa Fluor 647-bearing probe 17 in measuring the binding affinities of unlabeled $\mathrm{hA}_{2 \mathrm{~A}} \mathrm{AR}$ antagonists was 

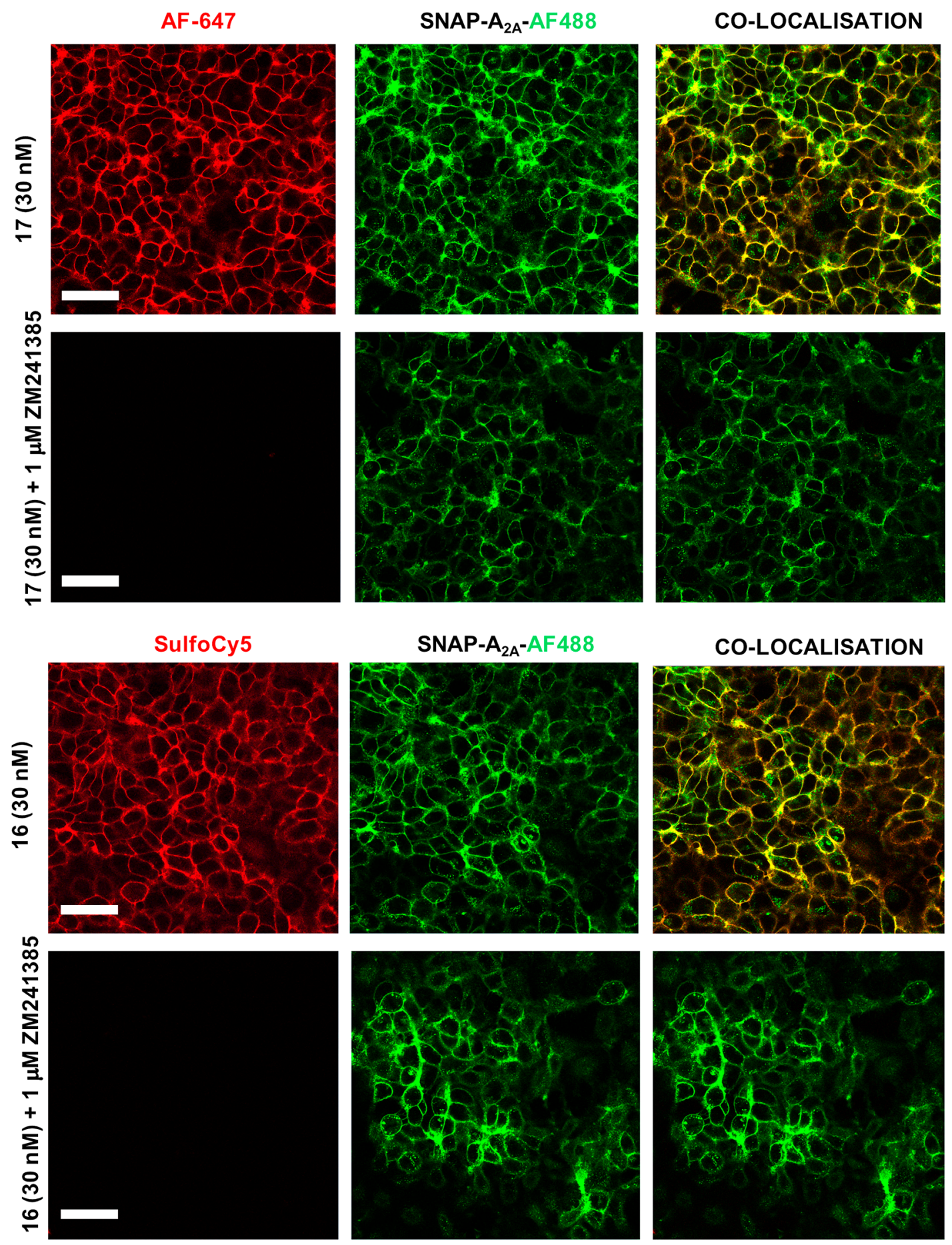

Figure 8. Live cell confocal imaging of $16(30 \mathrm{nM})$ and $17(30 \mathrm{nM})$ binding to SNAP-tagged $\mathrm{hA} \mathrm{A}_{2 \mathrm{AR}}$ expressed in HEK293 cells. Cells were incubated $30 \mathrm{~min}$ at $37^{\circ} \mathrm{C}$ with BG-Alexa Fluor 488 prior incubation in the absence or presence of $1 \mu \mathrm{M}$ ZM241385. Subsequently, cells were incubated with $30 \mathrm{nM}$ fluorescent ligand for $30 \mathrm{~min}$ at $37^{\circ} \mathrm{C}$ prior to imaging. The images generated are from one single experiment and are representative of three different experiments. The images were all captured using the same settings for laser power and detector gain. Scale bars are $50 \mu \mathrm{m}$.

investigated using the NanoBRET competition ligand binding assay. HEK293 cells transiently expressing the NanoLuc$\mathrm{hA}_{2 \mathrm{~A}} \mathrm{AR}$ were incubated with $17(50 \mathrm{nM})$ and increasing concentrations of the $\mathrm{hA}_{2 \mathrm{~A}} \mathrm{AR}$ antagonists $\mathrm{ZM} 241385$, SCH58261, SCH442416, and MRS1334, a selective adenosine $\mathrm{A}_{3} \mathrm{AR}$ antagonist which was used as negative control. A concentration dependent decrease of the BRET signal was observed for the $\mathrm{A}_{2 \mathrm{~A}} \mathrm{AR}$ selective compounds, allowing the binding affinities of the unlabeled antagonists to be measured (Figure 9 and Table 3). The values obtained through fluorescent binding assays were comparable to the reported literature values $\left(\mathrm{R}^{2}=0.97\right.$, Supporting Information, Figure S1) measured in radioligand binding experiments. ${ }^{4,59}$ No concentration-dependent decrease of the BRET signal was observed in the presence of the selective $A_{3} A R$ antagonist 


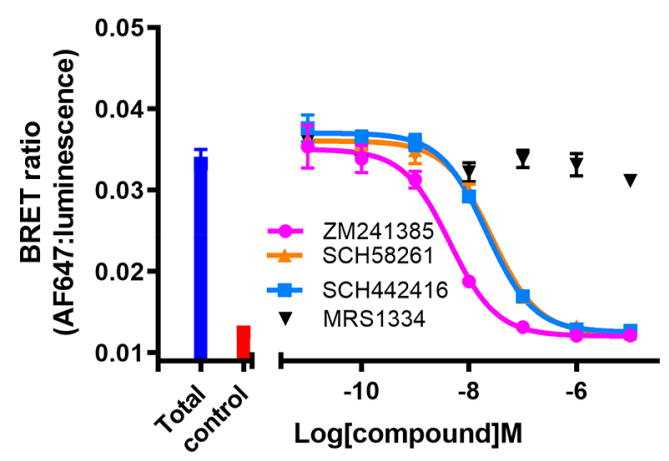

Figure 9. Displacement of $17(50 \mathrm{nM})$ by unlabeled $\mathrm{hA} \mathrm{A}_{2 \mathrm{~A}} \mathrm{AR}$ antagonists ZM241385, SCH58261, SCH442416, and $\mathrm{hA}_{3} \mathrm{AR}$ antagonist MRS1334 in HEK293G cells transiently expressing the Nanoluc- $h A_{2 A} A R$. Blue and red bars represent the total BRET signal of 17 in absence or presence of ZM241385 $(10 \mu \mathrm{M})$, respectively. The decrease in BRET ratio was monitored as a function of increasing concentration of unlabeled antagonist. Each data point represents mean value \pm SEM of triplicate determinations in a single representative experiment of $n=4$ experiments.

Table 3. Binding Affinities $\left(\mathrm{p} K_{\mathrm{i}}\right)$ of Target $\mathrm{hA}_{2 \mathrm{~A}} \mathrm{AR}$ Antagonists Calculated from Cheng-Prusoff Analysis of the Data Displayed in Figure 9

\begin{tabular}{lcc}
\multicolumn{1}{c}{ compd } & $\mathrm{p} K_{\mathrm{i}}$ (BRET binding assay) & $\mathrm{p} K_{\mathrm{i}}$ (literature $)^{a}$ \\
$\mathrm{ZM} 241385$ & $8.84 \pm 0.09$ & $8.80^{b}$ \\
$\mathrm{SCH} 58261$ & $7.92 \pm 0.10$ & $8.30^{c}$ \\
SCH442416 & $7.90 \pm 0.10$ & $8.38^{d}$
\end{tabular}

${ }^{a}$ Reported binding affinities of target $\mathrm{hA}_{2 \mathrm{~A}} \mathrm{AR}$ antagonists. ${ }^{b}$ Values determined in radioligand binding experiments in $\mathrm{CHO}-\mathrm{hA} \mathrm{A}_{2 \mathrm{~A}}$ and HEK293- $\mathrm{hA}_{2 \mathrm{~A}}$ cells using $\left[\mathrm{H}^{3}\right]$ SCH58261. ${ }^{59,60}{ }^{c}$ Values determined in radioligand binding experiments in $\mathrm{CHO}-\mathrm{hA} \mathrm{A}_{2 \mathrm{~A}}$ and $\mathrm{HEK} 293-\mathrm{hA}_{2 \mathrm{~A}}$ cells using $\left[\mathrm{H}^{3}\right]$ SCH58261. ${ }^{59,60}{ }^{d}$ Values determined in HEK293$\mathrm{hA}_{2 \mathrm{~A}}$ using the radiolabeled agonist $\left[{ }^{3} \mathrm{H}\right]$ CGS $21680 .{ }^{30}$ The data measured through NanoBRET competition ligand binding assay are means \pm SEM of $n=4$ experiments performed in triplicate.

MRS1224, confirming the specificity of the binding of the probe 17 to the $A_{2 A} A R$.

\section{CONCLUSION}

In the present study, we have reported the successful design, development, and pharmacological evaluation of a novel series of $\mathrm{hA}_{2 \mathrm{~A}} \mathrm{AR}$ fluorescent antagonists, encompassing BODIPYbearing probes and water-soluble Cy5-labeled and AF647labeled probes, based on the high affinity and selective preladenant scaffold. In particular, derivatization of the amino functionalized congener 11 with two families of fluorescent tags led to six $h A_{2 A} A R$ fluorescent antagonists with retained affinity and, most importantly, selectivity at the $\mathrm{A}_{2 \mathrm{~A}} \mathrm{AR}$ subtype. Both families of compounds allowed visualization of $A_{2 A} A R s$ expressed in live cells as demonstrated by the high fluorescence intensity at the cell membranes. The binding of these fluorescent ligands could be surmounted by a high concentration of ZM241385, confirming that the binding of the probes was specific. Very little nonspecific binding was observed for the water-soluble fluorescent antagonists (Figure 8). Within the water-soluble family of probes, fluorescent conjugate 17 was selected to successfully monitor ligand binding of reported $\mathrm{hA}_{2 \mathrm{~A}} \mathrm{AR}$ antagonists (Figure 9 and Table 3).
The novel $\mathrm{hA}_{2 \mathrm{~A}} \mathrm{AR}$ fluorescent ligands developed can be broadly applied in a series of fluorescence-based techniques to study the signaling and dynamics of the adenosine $A_{2 A} A R$ receptors in their native cellular environment spanning from in vitro to in vivo applications. Most importantly, we believe that these ligands in combination with the NanoBRET approach and bioimaging studies can help to shed light on the complexity of the $A_{2 A} A R$ signaling in different biological elements and during disease progression. This ultimately should provide useful insights concerning specific $\mathrm{A}_{2 \mathrm{~A}} \mathrm{AR}$ engagement in several disease phenotypes, including cancer. $13,61,62$

\section{EXPERIMENTAL SECTION}

Chemistry: Materials and Methods. Chemicals and solvents of analytical and HPLC grade were purchased from commercial suppliers and used without further purification. BODIPY630/650-XSE, BODIPY-FL-X-SE, and BODIPY-FL-SE were purchased from Molecular Probes (Thermo Fisher Scientific). Alexa Fluor 647 NHS ester was purchased from Thermo Fischer Scientific and sulfo-cyanine 5 NHS ester from Lumiprobe. All reactions were carried out at ambient temperature unless otherwise stated. Reactions were monitored by thin-layer chromatography on commercially available silica precoated aluminum-backed plates (Merck Kieselgel $60 \mathrm{~F}^{254}$ ). Visualization was under UV light (254 and $366 \mathrm{~nm}$ ), followed by staining with ninhydrin or $\mathrm{KMnO}_{4}$ dips. Flash column chromatography was performed using silica gel 60, 230-400 mesh particle size (Sigma-Aldrich). NMR spectra were recorded on a Bruker-AV 400. ${ }^{1} \mathrm{H}$ NMR spectra were recorded at $400.13 \mathrm{MHz}$ and ${ }^{13} \mathrm{C}$ NMR spectra at $101.62 \mathrm{MHz}$. All ${ }^{13} \mathrm{C}$ NMR are ${ }^{1} \mathrm{H}$ broadband decoupled. Solvents used for NMR analysis (reference peaks listed) were $\mathrm{CDCl}_{3}$ supplied by Cambridge Isotope Laboratories Inc. $(\delta \mathrm{H}=7.26 \mathrm{ppm}, \delta \mathrm{C}=$ 77.16). Chemical shifts $(\delta)$ are recorded in parts per million (ppm), and coupling constants are recorded in $\mathrm{Hz}$. The following abbreviations are used to described signal shapes and multiplicities; singlet $(\mathrm{s})$, doublet $(\mathrm{d})$, triplet $(\mathrm{t})$, quadruplet $(\mathrm{q})$, broad (br), dd (doublet of doublets), ddd (double doublet of doublets), dtd (double triplet of doublets), and multiplet $(\mathrm{m})$. Processing of the NMR data was carried out using the NMR software Topspin. LC-MS spectra were recorded on a Shimadzu UFLCXR system coupled to an Applied Biosystems API2000 and visualized at $254 \mathrm{~nm}$ (channel 1) and 220 $\mathrm{nm}$ (channel 2). LC-MS was carried out using a Phenomenex GeminiNX C18 110A, column $(50 \mathrm{~mm} \times 2 \mathrm{~mm} \times 3 \mu \mathrm{m})$ at a flow rate 0.5 $\mathrm{mL} / \mathrm{min}$ over a $5 \mathrm{~min}$ period $(\operatorname{method} \mathrm{A})$. All high resolution mass spectra (HRMS) were recorded on a Bruker microTOF mass spectrometer using MS electrospray ionization operating in positive ion mode. RP-HPLC was performed on a Waters $515 \mathrm{LC}$ system and monitored using a Waters 996 photodiode array detector at wavelengths between 190 and $800 \mathrm{~nm}$. Spectra were analyzed using Millenium 32 software. Semipreparative HPLC was performed using YMC-Pack C8 column $(150 \mathrm{~mm} \times 10 \mathrm{~mm} \times 5 \mu \mathrm{m})$ at a flow rate of $5.0 \mathrm{~mL} / \mathrm{min}$ using a gradient method of $20-70 \% \mathrm{~B}$ over $21 \mathrm{~min}$ (solvent $\mathrm{A}=0.01 \%$ formic acid in $\mathrm{H}_{2} \mathrm{O}$, solvent $\mathrm{B}=0.01 \%$ formic acid in $\mathrm{CH}_{3} \mathrm{CN}$ (method B)). Analytical RP-HPLC was performed using a YMC-Pack C8 column $(150 \mathrm{~mm} \times 4.6 \mathrm{~mm} \times 5 \mu \mathrm{m})$ and a Phenomenex Gemini NX-C18 column $(250 \mathrm{~mm} \times 4.6 \mathrm{~mm} \times 5 \mu \mathrm{m})$ at a flow rate of $1.0 \mathrm{~mL} / \mathrm{min}$. Final products were one single peak and $>98 \%$ pure. The retention time of the final product is reported using a gradient method of $10-90 \%$ solvent $\mathrm{B}$ in solvent $\mathrm{A}$ over $30 \mathrm{~min}$. (solvent $\mathrm{A}=0.01 \%$ formic acid in $\mathrm{H}_{2} \mathrm{O}$, solvent $\mathrm{B}=0.01 \%$ formic acid in $\mathrm{CH}_{3} \mathrm{CN}($ method $\mathrm{C})$ ).

General Procedure 1: Synthesis of Fluorescent Conjugates. The amine congener (as the di- $\mathrm{HCl}$ salt) was dissolved in DMF $(0.5 \mathrm{~mL})$, treated with DIPEA $(0.6 \mu \mathrm{L} 3.7 \mathrm{mmol}$, 4 equiv) and then reacted with BODIPY630/650-X-NHS (0.5 mg, 1 equiv), BODIPY-FL-X-NHS ( 1 equiv, $0.5 \mathrm{mg}$ ), BODIPY-FL-NHS ( 1 equiv, $0.5 \mathrm{mg}$ ), sulfo-cyanine 5-NHS ester (0.8 mg, 1 equiv), Alexa Fluor 647-NHS (0.8 mg, 1 equiv), and HATU (1.7 mg, 1 equiv) prior reacting with 
BODIPY630/650-carboxylic acid $(2 \mathrm{mg})$. The resulting solution was stirred at RT under the exclusion of light for $1-5 \mathrm{~h}$. Upon completion of the reaction monitored by LC-MS, the solution was concentrated to dryness and the residue was dissolved in $1: 1 \mathrm{CH}_{3} \mathrm{CN} / \mathrm{H}_{2} \mathrm{O}$. Purification by reverse phase-HPLC, followed by lyophilization, afforded the pure fluorescent conjugate.

7-(2-Chloroethyl)-2-(furan-2-yl)-7H-pyrazolo[4,3-e][1,2,4]triazolo[1,5-c]pyrimidin-5-amine (4). 2-Amino-4,6-dichloropyrimidine-5-carbaldehyde $(0.5 \mathrm{~g}, 2.6 \mathrm{mmol}, 1$ equiv) was dissolved in anhydrous THF $(20 \mathrm{~mL})$. To the resulting mixture was added $\mathrm{Et}_{3} \mathrm{~N}$ $(0.26 \mathrm{~g}, 2.86 \mathrm{mmol}, 1.1$ equiv) followed by 2 -furoic hydrazide $(0.36 \mathrm{~g}$, $2.86 \mathrm{mmol}, 1.1$ equiv). The above mixture was heated to $70{ }^{\circ} \mathrm{C}$ for 3 h. The mixture was then evaporated in vacuo to give intermediate 2 as yellow solid, which was used for the next reaction without further purification. LC-MS $m / z$ calcd for $\mathrm{C}_{10} \mathrm{H}_{9} \mathrm{ClN}_{5} \mathrm{O}_{3}[\mathrm{MH}]^{+}$: 282.04, found 282.10, $t_{R}=2.09 \min (\operatorname{method} \mathrm{A})$. To a solution of 2 ( 1 equiv) in $\mathrm{CH}_{3} \mathrm{CN} /$ water $(10: 2.5 \mathrm{~mL})$ was added 2-hydrazinoethanol $(0.35$ $\mathrm{mL}, 5.2 \mathrm{mmol}, 2$ equiv). The mixture was heated to reflux for $2.5 \mathrm{~h}$. The solution was allowed to cool at RT. Then $0.1 \mathrm{M} \mathrm{HCl}(5 \mathrm{~mL})$ was added to the reaction mixture. Afterward, the solution was evaporated in vacuo to $5 \mathrm{~mL}$ and left overnight for a solid to appear. Water (10 $\mathrm{mL}$ ) was added, and the solid was collected by filtration. The solid was further washed with $\mathrm{CH}_{3} \mathrm{CN}$ and $\mathrm{Et}_{2} \mathrm{O}$. The solid was dissolved in $\mathrm{MeOH}$, and the solution was evaporated azeotropically with toluene to give the desired compound 3 which was used for the next step without any further purification. LC-MS $\mathrm{m} / z$ calcd for $\mathrm{C}_{12} \mathrm{H}_{14} \mathrm{~N}_{7} \mathrm{O}_{3}[\mathrm{MH}]^{+}:$304.12, found 304.10, $t_{R}=0.61$ min (method A). Intermediate $3(0.550 \mathrm{~g}, 1.8 \mathrm{mmol}, 1$ equiv) was dissolved in $\mathrm{POCl}_{3}(4 \mathrm{~mL})$. To the resulting mixture was added $\mathrm{ZnBr}_{2}(0.1 \mathrm{~g})$. The mixture was heated to $80{ }^{\circ} \mathrm{C}$ for $5 \mathrm{~h}$. Then $\mathrm{POCl}_{3}$ was evaporated, water (ice) added, and the resulting aqueous solution was extracted with EtOAc. Organic layers were collected, dried over $\mathrm{Na}_{2} \mathrm{SO}_{4}$ anhydrous, filtered, and evaporated to dryness. Purification by flash column chromatography on silica gel using 2:1 EtOAc/ petroleum spirits gave a mixture of intermediates $4 a$ and $4 b$ as a paleyellow solid $(0.11 \mathrm{~g}$, yield $11 \%)$. LC-MS $m / z$ calcd for $\mathrm{C}_{12} \mathrm{H}_{11} \mathrm{ClN}_{7} \mathrm{O}$ $[\mathrm{MH}]^{+}:$304.07, found 304.10; calcd for $\mathrm{C}_{12} \mathrm{H}_{10} \mathrm{BrN}_{7} \mathrm{O}[\mathrm{MH}]^{+}$: 348.02 , found $348.10, t_{R}=2.50 \min (\operatorname{method} \mathrm{A}) .{ }^{1} \mathrm{H}$ NMR (DMSO$\left.d_{6}\right) \delta 8.23(\mathrm{~s}, J=1.0 \mathrm{~Hz}, 1 \mathrm{H}), 8.14($ brs, $2 \mathrm{H}), 7.95(\mathrm{~d}, J=1.8 \mathrm{~Hz}$, $1 \mathrm{H}), 7.24(\mathrm{~d}, J=3.3 \mathrm{~Hz}, 1 \mathrm{H}), 6.74(\mathrm{dd}, J=3.4,1.8 \mathrm{~Hz}, 1 \mathrm{H}), 4.66(\mathrm{t}, J$ $=6.2 \mathrm{~Hz}, 1 \mathrm{H}), 4.60(\mathrm{t}, J=5.9 \mathrm{~Hz}, 2 \mathrm{H}), 4.09(\mathrm{t}, J=5.9 \mathrm{~Hz}, 2 \mathrm{H}), 3.94$ $(\mathrm{t}, J=6.2 \mathrm{~Hz}, 1 \mathrm{H})$.

2-(2-((tert-Butoxycarbonyl)amino)ethoxy)ethyl 4-Methylbenzenesulfonate (6). tert-Butyl (2-(2-hydroxyethoxy) ethyl) carbamate ( $1 \mathrm{~g}, 4.87 \mathrm{mmol}, 1$ equiv) was dissolved in DCM $(20 \mathrm{~mL})$. To the resulting mixture were added DIPEA $(2.5 \mathrm{~mL}, 3$ equiv), DMAP $(5 \%$ $\mathrm{mol}$ ), and $\mathrm{TsCl}$ ( $1.85 \mathrm{~g}, 9.74 \mathrm{mmol}, 1.3$ equiv). The mixture was stirred at RT overnight. The solution was concentrated under reduced pressure to a volume of $5 \mathrm{~mL}$. Purification by flash column chromatography on silica gel using a gradient of $0 \rightarrow 4 \% \mathrm{MeOH} /$ DCM gave the desired product (1.5 g, yield $86 \%)$. LC-MS $m / z$ calcd for $\mathrm{C}_{16} \mathrm{H}_{26} \mathrm{NO}_{6} \mathrm{~S}[\mathrm{MH}]^{+}: 360.15$, found $360.10, t_{R}=2.51 \mathrm{~min}$ $(\operatorname{method~A}) .{ }^{1} \mathrm{H}$ NMR $\left(\mathrm{CDCl}_{3}\right) \delta 7.80(\mathrm{~d}, J=8.0 \mathrm{~Hz}, 2 \mathrm{H}), 7.35(\mathrm{~d}, J$ $=7.96 \mathrm{~Hz}, 2 \mathrm{H}), 4.80(\mathrm{brs}, 1 \mathrm{H}), 4.16(\mathrm{t}, J=4.1 \mathrm{~Hz}, 2 \mathrm{H}), 3.63(\mathrm{t}, J=$ $4.3 \mathrm{~Hz}, 2 \mathrm{H}), 3.45(\mathrm{t}, J=4.4 \mathrm{~Hz}, 2 \mathrm{H}), 3.24(\mathrm{q}, J=5.4 \mathrm{~Hz}, 2 \mathrm{H}), 2.45$ $(\mathrm{s}, 3 \mathrm{H}), 1.45(\mathrm{~s}, 9 \mathrm{H}) .{ }^{13} \mathrm{C} \mathrm{NMR}\left(\mathrm{CDCl}_{3}\right) \delta 155.9,145.0,133.1$, 129.9, 128.1, 79.4, 70.4, 69.2, 68.4, 40.3, 28.5, 21.7.

Benzyl 4-(4-Hydroxyphenyl)piperazine-1-carboxylate (8). Benzyl chloroformate $(0.793 \mathrm{~mL}, 5.6 \mathrm{mmol}, 1$ equiv) was added to a stirred suspension of 4-(piperazin-1-yl) phenol (1.0 g, $5.6 \mathrm{mmol}, 1 \mathrm{eq})$ and $\mathrm{K}_{2} \mathrm{CO}_{3}(0.93 \mathrm{~g}$, $6.7 \mathrm{mmol}, 1.2 \mathrm{eq})$ in DMF $(8 \mathrm{~mL})$. Water was then added, and the aqueous layer was extracted with EtOAc. The organic layer was further washed with water $(\times 3)$, dried over anhydrous $\mathrm{Na}_{2} \mathrm{SO}_{4}$, filtered, and evaporated to dryness. Purification by flash column chromatography on silica using $40 \%$ EtOAc/petroleum ether gave the desired product $(1.2 \mathrm{~g}$, yield $66 \%)$. LC-MS $\mathrm{m} / z$ calcd for $\mathrm{C}_{18} \mathrm{H}_{21} \mathrm{~N}_{2} \mathrm{O}_{3}[\mathrm{MH}]^{+}: 313.15$, found 313.10, $t_{R}=2.51$ min (method A). ${ }^{1} \mathrm{H} \mathrm{NMR}\left(\mathrm{CDCl}_{3}\right) \delta 7.39-7.31(\mathrm{~m}, 5 \mathrm{H}), 6.85(\mathrm{~d}, J=8.4 \mathrm{~Hz} 2 \mathrm{H})$, $6.77(\mathrm{~d}, J=7.6 \mathrm{~Hz}, 2 \mathrm{H}), 5.17(\mathrm{brs}, 1 \mathrm{H}), 5.00(\mathrm{~s}, 2 \mathrm{H}), 3.66(\mathrm{t}, J=4.63$ $\mathrm{Hz} 4 \mathrm{H}), 3.01(\mathrm{~m}, 4 \mathrm{H}) .{ }^{13} \mathrm{C} \mathrm{NMR}\left(\mathrm{CDCl}_{3}\right) \delta 155.1,136.4,128.4$,
$127.9,127.8,119.1,115.8,67.1,50.9,43.7$ (two quaternary carbons in the phenol not observed).

Benzyl 4-(4-(2-(2-((tert-Butoxycarbonyl)amino)ethoxy)ethoxy)phenyl)piperazine-1-carboxylate (9i). Compound 8 (0.36 g, 1.16 mmol) was dissolved in $\mathrm{CH}_{3} \mathrm{CN}(10 \mathrm{~mL}) \cdot \mathrm{K}_{2} \mathrm{CO}_{3}(0.5 \mathrm{~g})$ was subsequently added to the reaction mixture, followed by compound 6 $(0.416 \mathrm{~g}, 1.16 \mathrm{mmol}, 1$ equiv). The resulting mixture was heated to $100{ }^{\circ} \mathrm{C}$ and held at this temperature for $6 \mathrm{~h}$. The reaction was allowed to cool, $\mathrm{Et}_{2} \mathrm{O}$ was added, and the mixture was washed with $1 \mathrm{M}$ $\mathrm{NaOH}(\times 3)$. The organic layer was collected and evaporated to dryness. Purification by flash column chromatography on silica using $60 \% \mathrm{EtOAc} /$ petroleum ether gave the final product as an off-white solid (0.2 g, yield $40 \%)$. LC-MS $m / z$ calcd for $\mathrm{C}_{27} \mathrm{H}_{38} \mathrm{~N}_{3} \mathrm{O}_{6}[\mathrm{MH}]^{+}$: 500.28 , found $500.10, t_{R}=3.02 \min (\operatorname{method} \mathrm{A}) .{ }^{1} \mathrm{H}$ NMR $\left(\mathrm{CDCl}_{3}\right)$ $\delta 7.40-7.32(\mathrm{~m}, 5 \mathrm{H}), 6.88(\mathrm{~s}, 4 \mathrm{H}), 5.16(\mathrm{~s}, 2 \mathrm{H}), 4.98(\mathrm{brs}, 1 \mathrm{H}), 4.07$ $(\mathrm{t}, J=4.3 \mathrm{~Hz}, 2 \mathrm{H}), 3.79(\mathrm{t}, J=4.5 \mathrm{~Hz}, 2 \mathrm{H}), 3.66(\mathrm{t}, J=4.8 \mathrm{~Hz}, 4 \mathrm{H})$, $3.60(\mathrm{t}, J=4.8 \mathrm{~Hz}, 2 \mathrm{H}), 3.34(\mathrm{q}, J=4.6 \mathrm{~Hz}, 2 \mathrm{H}), 3.07-2.97(\mathrm{~m}, 4 \mathrm{H})$, $1.44(\mathrm{~s}, 9 \mathrm{H}) .{ }^{13} \mathrm{C}$ NMR $\left(\mathrm{CDCl}_{3}\right) \delta 155.4,150.1,136.4,128.4,127.9$, $127.79,115.3,70.2,69.4,67.6,67.1,50.7,43.7,40.2,28.2$.

tert-Butyl (2-(2-(4-(Piperazin-1-yl)phenoxy)ethoxy)ethyl)carbamate (9ii). Compound $9 \mathrm{i}(0.2 \mathrm{~g}, 1$ equiv) was dissolved in $\mathrm{EtOH}(4 \mathrm{~mL})$, and the resulting mixture was stirred at RT under a nitrogen atmosphere. $\mathrm{Pd} / \mathrm{C} 11 \% \mathrm{w} / \mathrm{w}$ was added to the reaction mixture, and the flask was evacuated and replaced with a $\mathrm{H}_{2}$ atmosphere. The reaction was stirred at RT for $3 \mathrm{~h}$. The completion of the reaction was confirmed by TLC. The mixture was then filtered through Celite, and the pad was washed with EtOH $(40 \mathrm{~mL})$ and DCM $(40 \mathrm{~mL} \times 3)$. The filtrate was collected and concentrated under reduced pressure to give the pure product as an off-white solid $(0.12$ g, yield 82\%). LC-MS $m / z$ calcd for $\mathrm{C}_{19} \mathrm{H}_{32} \mathrm{~N}_{3} \mathrm{O}_{4}[\mathrm{MH}]^{+}: 366.24$, found 366.10, $t_{R}=2.12 \min (\operatorname{method} \mathrm{A}) .{ }^{1} \mathrm{H}$ NMR $\left(\mathrm{CDCl}_{3}\right) \delta 6.92-$ $6.84(\mathrm{~m}, 4 \mathrm{H}), 5.00(\mathrm{brs}, 1 \mathrm{H}), 4.07(\mathrm{t}, J=4.4 \mathrm{~Hz}, 2 \mathrm{H}), 3.79(\mathrm{t}, J=4.4$ $\mathrm{Hz}, 2 \mathrm{H}), 3.60(\mathrm{t}, J=4.4 \mathrm{~Hz}, 2 \mathrm{H}), 3.47(\mathrm{~s}, 1 \mathrm{H}), 3.33(\mathrm{q}, J=4.8 \mathrm{~Hz}$, $2 \mathrm{H}), 3.05(\mathrm{~s}, 7 \mathrm{H}), 1.44(\mathrm{~s}, 9 \mathrm{H}) .{ }^{13} \mathrm{C} \mathrm{NMR}\left(\mathrm{CDCl}_{3}\right) \delta 156.1,153.1$, 146.5, 118.4, 115.5, 79.37, 70.5, 69.7, 67.9, 51.7, 46.2, 40.5, 28.5.

tert-Butyl (2-(2-(4-(4-(2-(5-Amino-2-(furan-2-yl)-7H-pyrazolo[4,3-e][1,2,4]triazolo[1,5-c]pyrimidin-7-yl)ethyl)piperazin-1-yl)phenoxy)ethoxy)ethyl)carbamate (10). tert-Butyl (2-(2-(4-(piperazin-1-yl)phenoxy)ethoxy)ethyl)carbamate (30 mg, $0.9 \mu \mathrm{mol}, 1$ equiv) and 4 ( $40 \mathrm{mg}, 1.1 \mu \mathrm{M}, 1$ equiv) were dissolved in DMF $(0.5 \mathrm{~mL})$ prior to the addition of DIPEA (4 equiv, $0.4 \mathrm{~mL}$ ). The resulting mixture was heated and held at $100{ }^{\circ} \mathrm{C}$ overnight. Completion of the reaction was confirmed by TLC. The solution was further dissolved in EtOAc and washed with water $(\times 3)$. The organic layer was collected and concentrated under reduced pressure. Purification by flash column chromatography on silica using DCM:MeOH (96:4) gave the pure compound as a pale-yellow solid (12 mg, yield $19 \%$ ). LC-MS $m / z$ calcd for $\mathrm{C}_{31} \mathrm{H}_{41} \mathrm{~N}_{10} \mathrm{O}_{5}[\mathrm{MH}]^{+}$: 633.33, found 633.10, $t_{R}=2.12 \min (\operatorname{method} \mathrm{A}) .{ }^{1} \mathrm{H} \operatorname{NMR}\left(\mathrm{CDCl}_{3}\right)$ $\delta 8.18(\mathrm{~s}, 1 \mathrm{H}), 7.53(\mathrm{~d}, J=1.8 \mathrm{~Hz}, 1 \mathrm{H}), 7.21(\mathrm{~d}, J=3.4 \mathrm{~Hz}, 1 \mathrm{H})$, $6.88-6.81(\mathrm{~m}, 4 \mathrm{H}), 6.56(\mathrm{dd}, J=3.5,1.8 \mathrm{~Hz}, 1 \mathrm{H}), 6.45(\mathrm{brs}, 2 \mathrm{H})$, $5.01($ brs, $1 \mathrm{H}), 4.53(\mathrm{t}, J=6.42 \mathrm{~Hz}, 2 \mathrm{H}), 4.05(\mathrm{t}, J=3.72 \mathrm{~Hz}, 2 \mathrm{H})$, $3.78(\mathrm{t}, J=4.2 \mathrm{~Hz}, 2 \mathrm{H}), 3.59(\mathrm{t}, J=4.1 \mathrm{~Hz}, 2 \mathrm{H}), 3.33(\mathrm{q}, J=5.1 \mathrm{~Hz})$ $3.14-3.07(\mathrm{~m}, 4 \mathrm{H}), 2.98(\mathrm{t}, J=6.00 \mathrm{~Hz}, 2 \mathrm{H}), 2.78-2.69(\mathrm{~m}, 4 \mathrm{H})$, $1.43(\mathrm{~s}, 9 \mathrm{H}) .{ }^{13} \mathrm{C} \mathrm{NMR}\left(\mathrm{CDCl}_{3}\right) \delta 156.7,156.1,152.9,149.3,148.3$, $145.9,145.5,145.5,144.7,132.3,118.1,115.5,112.7,112.1,97.4$, 79.4, 70.5, 69.7, 67.9, 57.0, 53.4, 50.4, 45.3, 40.5, 28.5.

7-(2-(4-(4-(2-(2-Aminoethoxy)ethoxy)phenyl)piperazin-1-yl)ethyl)-2-(furan-2-yl)-7H-pyrazolo[4,3-e][1,2,4]triazolo[1,5-c]pyrimidin-5-amine (11). Compound 10 (12 mg, 1 equiv) was dissolved in $4 \mathrm{M} \mathrm{HCl}$ in dioxane $(1 \mathrm{~mL})$. The completion of the reaction was confirmed by TLC and LC-MS after $30 \mathrm{~min}$. The solvent was removed under reduced pressure and the compound was used in the next synthetic step without further purification $(10 \mathrm{mg}$, quantitative $100 \%$ ). LC-MS $\mathrm{m} / z$ calcd for $\mathrm{C}_{26} \mathrm{H}_{33} \mathrm{~N}_{10} \mathrm{O}_{3}[\mathrm{MH}]^{+}$: 533.27, found 533.10, $t_{R}=1.85 \min (\operatorname{method} \mathrm{A})$.

(E)-N-(2-(2-(4-(4-(2-(5-Amino-2-(furan-2-yl)-7H-pyrazolo[4,3-e][1,2,4]triazolo[1,5-c]pyrimidin-7-yl)ethyl)piperazin-1-yl)phenoxy)ethoxy)ethyl)-6-(2-(4-(2-(5,5-difluoro-7-(thiophen-2-yl)-5H-5I ${ }^{4}, 6 \mathrm{I}^{4}$ dipyrrolo $\left[1,2-c: 2^{\prime}, 1^{\prime}-f\right][1,3,2]$ diazaborinin-3-yl)vinyl)phenoxy)acetamido)hexanamide (12). Following general procedure 1, amine 
congener 11 ( $0.5 \mathrm{mg}, 1$ equiv) was converted to the BODIPY630/ $650-\mathrm{X}$ conjugate 12. Purification by RP-HPLC (method B) gave, after lyophilization, the title compound as a blue solid (1.1 $\mathrm{mg} 98 \%$ ). Analytical RP-HPLC $t_{R}=15.48 \mathrm{~min}$ (method C), purity $>98 \%$. HRMS (ESI-TOF) calcd for $\mathrm{C}_{55} \mathrm{H}_{59} \mathrm{BF}_{2} \mathrm{~N}_{13} \mathrm{O}_{6} \mathrm{~S}[\mathrm{M}+\mathrm{H}]^{+}$: 1078.4488, found 1078.4508 and $1100.4307[\mathrm{M}+\mathrm{Na}]$.

(E)-N-(2-(2-(4-(4-(2-(5-Amino-2-(furan-2-yl)-7H-pyrazolo[4,3-e][1,2,4]triazolo[1,5-c]pyrimidin-7-yl)ethyl)piperazin-1-yl)phenoxy)ethoxy)ethyl)-2-(4-(2-(5,5-difluoro-7-(thiophen-2-yl)-5H-4I ${ }^{4}, 5 \mathrm{I}^{4}$ dipyrrolo[1,2-c:2', $\left.1^{\prime}-f\right][1,3,2]$ diazaborinin-3-yl)vinyl)phenoxy)acetamide (13). Following general procedure 1, amine congener 11 ( 1 equiv, $0.5 \mathrm{mg}$ ) was converted to the BODIPY630/650 conjugate 13. Purification by RP-HPLC (method B) gave, after lyophilization, the title compound as a blue solid ( $1 \mathrm{mg}$, yield 56\%). Analytical RPHPLC $t_{R}=15.30$ min (method C), purity $>99 \%$. HRMS $\left(\right.$ TOF ES $\left.^{+}\right)$ calcd for $\mathrm{C}_{49} \mathrm{H}_{48} \mathrm{BF}_{2} \mathrm{~N}_{12} \mathrm{O}_{5} \mathrm{~S}[\mathrm{M}+\mathrm{H}]^{+}$: 965.3574, found 965.3593 .

$\mathrm{N}$-(2-(2-(4-(4-(2-(5-Amino-2-(furan-2-yl)-7H-pyrazolo[4,3-e][1,2,4]triazolo[1,5-c]pyrimidin-7-yl)ethyl)piperazin-1-yl)phenoxy)ethoxy)ethyl)-6-(3-(5,5-difluoro-7,9-dimethyl-5 H-4l ${ }^{4}, 5 \mathrm{I}^{4}$-dipyrrolo[1,2-c:2', 1'-f][1,3,2]diazaborinin-3-yl)propanamido)hexanamide (14). Following general procedure 1 , amine congener 11 (1 equiv, 0.5 $\mathrm{mg}$ ) was converted to the BODIPY-FL-X conjugate 14. Purification by RP-HPLC (method B) gave, after lyophilization, the title compound as an orange solid, (1.2 mg, yield 70\%). Analytical RPHPLC $t_{R}=13.04 \mathrm{~min}\left(\right.$ method C) purity $>99 \%$. HRMS $\left(\right.$ TOF ES $\left.^{+}\right)$ calcd for $\mathrm{C}_{46} \mathrm{H}_{57} \mathrm{BF}_{2} \mathrm{~N}_{13} \mathrm{O}_{5}[\mathrm{MH}]^{+}$: 920.4588, found 920.4660 .

$\mathrm{N}$-(2-(2-(4-(4-(2-(5-Amino-2-(furan-2-yl)-7H-pyrazolo[4,3-e][1,2,4]triazolo[1,5-c]pyrimidin-7-yl)ethyl)piperazin-1-yl)phenoxy)ethoxy)ethyl)-3-(5,5-difluoro-7,9-dimethyl-5 H-4 ${ }^{4}, 51^{4}$-dipyrrolo [1,2$\left.c: 2^{\prime}, 1^{\prime}-f\right][1,3,2]$ diazaborinin-3-yl)propanamide (15). Following general procedure 1, amine congener 11 ( 1 equiv, $0.5 \mathrm{mg}$ ) was converted to the BODIPY-FL conjugate 15. Purification by RP-HPLC (method B) gave, after lyophilization, the title compound as an orange solid $(0.7 \mathrm{mg}$, yield $100 \%)$. Analytical RP-HPLC $t_{R}=13.13 \mathrm{~min}$ (method C), purity $>99 \%$. HRMS (TOF ES $^{+}$calcd for $\mathrm{C}_{40} \mathrm{H}_{46} \mathrm{BF}_{2} \mathrm{~N}_{12} \mathrm{O}_{4}$ $[\mathrm{MH}]^{+}$: 807.3821, found 807.3820; calcd for $\mathrm{C}_{40} \mathrm{H}_{45} \mathrm{BF}_{2} \mathrm{~N}_{12} \mathrm{O}_{4} \mathrm{Na}[\mathrm{M}$ $+\mathrm{Na}]: 829.3640$, found 829.3627 .

1-(6-((2-(2-(4-(4-(2-(5-Amino-2-(furan-2-yl)-7H-pyrazolo[4,3-e]$[1,2,4]$ triazolo[1,5-c]pyrimidin-7-yl)ethyl)piperazin-1-yl)phenoxy)ethoxy)ethyl)amino)-6-oxohexyl)-3,3-dimethyl-2-((TE,3E)-5-((E)1,3,3-trimethyl-5-sulfoindolin-2-ylidene)penta-1,3-dien-1-yl)-3Hindol-1-ium-5-sulfonate (16). Following general procedure 1, amine congener 11 ( 1 equiv, $0.5 \mathrm{mg}$ ) was converted to sulfo-cyanine-5 conjugate 16. Purification by RP-HPLC (method B) gave, after lyophilization, the title compound as bright-blue solid $(1.9 \mathrm{mg}$, yield quantitative $100 \%$ ) pure. Analytical RP-HPLC $t_{R}=12.41 \mathrm{~min}$ (method C) purity $>99 \%$. HRMS (TOF ES ${ }^{-}$) $\mathrm{C}_{58} \mathrm{H}_{68} \mathrm{~N}_{12} \mathrm{O}_{10} \mathrm{~S}_{2}$ $[\mathrm{MH}]^{-}$: calcd 1155.4550 , found 1155.4547

3-(6-((2-(2-(4-(4-(2-(5-Amino-2-(furan-2-yl)-7H-pyrazolo[4,3-e][1,2,4]triazolo[1,5-c]pyrimidin-7-yl)ethyl)piperazin-1-yl)phenoxy)ethoxy)ethyl)amino)-6-oxohexyl)-2-((1E,3E)-5-((E)-3,3-dimethyl-5sulfo-1-(3-sulfopropyl)indolin-2-ylidene)penta-1,3-dien-1-yl)-3methyl-5-sulfo-1-(3-sulfopropyl)-3H-indol-1-ium (17). Following general procedure 1, amine congener 11 (1 eq., $0.5 \mathrm{mg}$ ) was converted to the Alexa Fluor 647 conjugate 17. Purification by RPHPLC (method B) gave the title compound as bright-blue solid (1.8 $\mathrm{mg}$ quantitative $100 \%$ ). Analytical RP-HPLC $t_{R}=10.58 \mathrm{~min}$ (method C) purity $>99 \%$. HRMS (TOF $\mathrm{ES}^{-}$) calcd for $\mathrm{C}_{62} \mathrm{H}_{76} \mathrm{~N}_{12} \mathrm{O}_{16} \mathrm{~S}_{4}$ $[\mathrm{MH}]^{-}$: 1372.4355 , found 1372.4391; $[\mathrm{M}-2]^{-}$: calcd 685.2120, found 685.2122 .

Molecular Modeling of Preladenant. Docking of preladenant to the high resolution $\mathrm{hA}_{2 \mathrm{~A}} \mathrm{AR}$ crystal structure was performed using Schrodinger software suite (release 2018-3). The $1.8 \AA$ resolution $\mathrm{hA}_{2 \mathrm{~A}} \mathrm{AR}$ crystal structure was imported from the Protein Data Bank (PDB 4EIY) and was prepared with the Protein Preparation Wizard program. This involved removal of water molecules, cocrystallized head groups, with the exclusion of the cocrystallized ligand ZM241385, and the addition of hydrogen atoms. The H-bonding network was optimized using PROPKA at $\mathrm{pH}=7$, and ultimately the protein structure was energy minimized by using OPLS3 force field. The docking site was defined with Glide Grid generation by using the coordinates of the cocrystallized ligand ZM241385. Preladenant was prepared for docking using LigPrep program. Molecular docking of preladenant was performed using Glide with XP (extra precision) mode and flexible ligand sampling without applying any restriction. Ten poses were generated, and the highest glide scoring pose was selected and modeled with PyMOL (version 2.2.0) to include key binding residues and distances measurements.

Pharmacology: Material and Methods. Cell culture reagent were purchased from Sigma Chemicals (Pool, Dorset, UK) except Fetal Calf Serum (FCS), which was provided by PAA Laboratories (Teddington, Middlesex, UK). G418 and Optimem were obtained from Life Technologies (Paisley, UK). SNAP-Lumi4-Tb was obtained by Cisbio Bioassays (Bagnols-sur-Cèze, France). All plates were obtained from Corning Costar (Corning Incorporated, Corning, NY, USA) unless otherwise stated. FuGENE transfection reagent and furimazine were purchased from Promega (Southampton, UK). ZM243185 was purchased from Tocris Bioscience (Bristol, UK). All other chemical and reagents were purchased from Sigma-Aldrich (Gillingham, UK)

Cell Culture. A CHO cell line stably expressing cAMP response element-secreted placental alkaline phosphatase (CRE-SPAP) reporter gene and the human $\mathrm{A}_{2} \mathrm{AR}$ were generated as previously described. $^{55} \mathrm{CHO} \mathrm{A}_{2 \mathrm{~A}}$ CRE-SPAP cell lines were cultured in Dulbecco's Modified Eagle's Medium (DMEM-F12) nutrient mix supported by $10 \%$ heat-inactivated FCS and $2 \mathrm{mM}$ L-glutamine. HEK293 cells stably expressing NanoLuc- $A_{1}$ and NanoLuc- $A_{3}$ were as described previously. ${ }^{3}$ To generate cells stably expressing the NanoLuc- $A_{2 B}$ HEK293 cells were stably transfected with pcDNANanoLuc- $A_{2 B}$ using FUGENE reagent, following the manufacturer's instructions, using 2:1 reagent:DNA ratio. Transfected cells were selected using $1 \mu \mathrm{g} / \mathrm{mL}$ G418. Cells were cultured in DMEM supplemented with $10 \%$ FCS. A SNAP-tagged HEK293 cell line stably expressing the human SNAP-A $\mathrm{A}_{2} \mathrm{AR}$ was generated by Dr. Laura Kilpatrick, who performed the transfection, dilution cloning, and isolation of a stable clone line. HEK293 cells expressing the GloSensor cAMP bionsensor (HEK293G) were obtained from Promega (United States). The HEK293 cell lines were maintained in DMEM containing 10\% FCS and $2 \mathrm{mM}$ L-glutamine and were grown to $70-80 \%$ confluency in $75 \mathrm{~cm}^{2}$ tissue culture flask before splitting. All cell colonies were incubated at $37{ }^{\circ} \mathrm{C}, 5 \% \mathrm{CO}_{2}$, and the tissue culture procedures were performed in a class II laminar flow hood using sterile conditions. Transient Transfection of NanoLuctagged human $\mathrm{A}_{2} \mathrm{AR}$ in HEK293G cell line was carried out as follows: $72 \mathrm{~h}$ prior the experiment cells were removed from a confluent T75 flask and centrifuged. The pellet of cells was resuspended in $10 \mathrm{~mL}$ of fresh complete DMEM. Afterward, each CORNING $10 \mathrm{~mm} \times 20 \mathrm{~mm}$ style dish was seeded with a density of $3 \times 10^{6}$ cells per dish in $10 \mathrm{~mL}$ of complete DMEM. Then $48 \mathrm{~h}$ prior the experiment transfection of the NanoLuc-tagged human $\mathrm{A}_{2} \mathrm{AR}$ in HEK $293 \mathrm{G}$ cell line was carried out using a mixture of $6 \mu \mathrm{g}$ DNA and $12 \mu \mathrm{L}$ of FuGENE(1:2 ratio) in $880 \mu \mathrm{L}$ of OptiMEM, followed by $5 \mathrm{~min}$ incubation at room temperature to allow the DNA:FuGENE complex to form. After that time, the entire mixture was carefully added to the CORNING dish and incubated at $37{ }^{\circ} \mathrm{C}, 5 \% \mathrm{CO}_{2}$ overnight. Then $24 \mathrm{~h}$ prior to the experiment day, cells were removed from a confluent dish and centrifuged. The pellet of cells was resuspended in $10 \mathrm{~mL}$ of fresh DMEM, and the resulting NanoLuc-tagged $h \mathrm{~A}_{2} \mathrm{AR}$ HEK293G cells were seeded in white Thermo Scientific 96-well plates at a density of 32000 cells/well and grown in normal growth medium. Terbium labeling of SNAP-tagged $A_{2 A} A R$ cells: To terbium label the SNAPHEK293- $A_{2 A} A R$ cells, cell culture media was removed from confluent SNAP-HEK293- $A_{2 A}$ AR cells contained in $T 175 \mathrm{~cm}^{2}$ flasks, washed once in DPBS, and then incubated with $100 \mathrm{nM}$ of SNAP-Lumi4-Tb in $1 x$ LabMed buffer for $1 \mathrm{~h}$ at $37{ }^{\circ} \mathrm{C}, 5 \% \mathrm{CO}_{2}$. Then the terbium labeling reagent was removed, and cells were washed once with icecold $15 \mathrm{~mL}$ of PBS. The cells were then removed from the wall of the flask by scraping and centrifuged at $2000 \mathrm{rpm}$ for $10 \mathrm{~min}$, and the resulting cell pellets were stored at $-80{ }^{\circ} \mathrm{C}$. Membrane preparations of Terbium-labeled SNAP-HEK293- $A_{2 A}$ AR cells: The following described steps were conducted at $4{ }^{\circ} \mathrm{C}$ to circumvent receptor degradation. Thawed pellets of cells were resuspended in PBS and homogenized 
using an electronical homogenizer, $10 \times 2 \mathrm{~s}$ bursts. Homogenized solution of cells was centrifuged at $1500 \mathrm{rpm}$ for $20 \mathrm{~min}$ to remove unbroken cells and nuclei. The supernatant was subsequently centrifuged at $41415 \mathrm{~g}$ for $30 \mathrm{~min}$. The resulting pellet was resuspended in $4 \mathrm{~mL}$ of $\mathrm{PBS}$ and fully homogenized. Protein concentration was determined using a BCA protein assay and membranes were stored at $-80{ }^{\circ} \mathrm{C}$ until required. Before their use, frozen membranes were thawed and suspended in HBSS buffer

Experiments. NanoBRET. HEK 293 cells were transiently transfected to express NanoLuc- $A_{2 A} A R$. HEK293 cells expressing NanoLuc-AR were seeded in white Termo Scientific 96-well plates and grown $24 \mathrm{~h}$ prior to the day of the experiment in normal growth medium. Before the experiment, DMEM was replaced with HBSS. For saturation and competition assays, the required concentration of fluorescent ligands, and competing ligand was added at the same time. Thereafter, plates were incubated for $2 \mathrm{~h}$ at $37{ }^{\circ} \mathrm{C}$. After $2 \mathrm{~h}, 10 \mu \mathrm{M}$ furimazine (1:40 dilution; Promega) was added to each well. After 5 min of incubation at $37{ }^{\circ} \mathrm{C}$, bioluminescence emission at two different wavelenghts was measured using a PHERAstar FS plate reader (BMG Labtech) at room temperature. The filter light emissions were read at $420 \mathrm{~nm}$ ( $80 \mathrm{~nm}$ bandpass) and $535 \mathrm{~nm}$ (60 nm bandpass) for BYFLlabeled ligands and at $420 \mathrm{~nm}$ ( $80 \mathrm{~nm}$ bandpass) and $>610 \mathrm{~nm}$ (longapass) for the BY630/Cy5/AF647-labeled ligands. The raw BRET ratio was calculated by dividing the $>610 \mathrm{~nm}$ emission or 533 $\mathrm{nm}$ emission by the $420 \mathrm{~nm}$ emission. The term "raw BRET ratio" refers to the unprocessed data as no background ratio has been subtracted.

CRE-SPAP Assay. First, $48 \mathrm{~h}$ prior to the experiment day, $\mathrm{CHO}$ CRE-SPAP $\mathrm{A}_{2} \mathrm{AR}$ cells were seeded onto clear 96-well plates and subsequently serum starved $24 \mathrm{~h}$ before the experiment employing DMEM-12 supplemented with $2 \mathrm{mM}$ L-glutamine (serum-free media). On the day of the assay, serum-free media was added to the cells and the fluorescent compounds under investigation were further added to the appropriate well at three concentrations $(10,100$, $1000 \mathrm{nM}$ ), and the plates were incubated for $30 \mathrm{~min}$ at $37^{\circ} \mathrm{C}, 5 \%$ $\mathrm{CO}_{2}$. After $30 \mathrm{~min}, \mathrm{NECA}$ was added at increasing concentrations and the plates were incubated for further $5 \mathrm{~h}$ at $37^{\circ} \mathrm{C} / 5 \% \mathrm{CO}_{2}$. Following $5 \mathrm{~h}$ incubation, the media was removed and replaced with $40 \mu \mathrm{L}$ of serum-free media. The plates were further incubated for $1 \mathrm{~h}$ at $37^{\circ} \mathrm{C} /$ $5 \% \mathrm{CO}_{2}$. Following $1 \mathrm{~h}$ incubation the plates were moved to an oven at $65{ }^{\circ} \mathrm{C}$ for $30 \mathrm{~min}$ in order to degrade endogenous alkaline phosphatases. The plates were then allowed to cool to room temperature, and $100 \mu \mathrm{L}$ of $5 \mathrm{mM}$ of 4-p-nitrophenyl phosphate in DEA buffer (100 nM diethanolamine; $280 \mathrm{nM} \mathrm{NaCl}$; $0.5 \mathrm{nM} \mathrm{MgCl}_{2}$. $\left.6 \mathrm{H}_{2} \mathrm{O}, \mathrm{pH}=9.85\right)$ were added in each well and the plates incubated at $37^{\circ} \mathrm{C}$ for $15 \mathrm{~min}$. Once the yellow color has developed, the plates were read on the Dynex MRX plate reader, which measured the absorbance at $405 \mathrm{~nm}$.

HTRF Binding Kinetic of BODIPY-630/650-X Conjugate 12. To determine the binding kinetics of fluorescent conjugate 12, HEK293 SNAP- $h \mathrm{~A}_{2 \mathrm{~A}} \mathrm{AR}$ cell membranes were diluted to the required concentration $(10 \mu \mathrm{g} /$ well) in HBSS buffer containing saponin (1 $\mathrm{mg} / \mathrm{mL}$ ) and added in white Thermo Scientific 96-well microplates. Fluorescent conjugate $\mathbf{1 2}$ was added simultaneously at four different concentrations in the presence and absence of $10 \mu \mathrm{M}$ ZM241385 to define nonspecific binding. The plates were read immediately: each well was read every $30 \mathrm{~s}$ for $60 \mathrm{~min}$. TR-FRET signals were acquired in a PHERAstarFS plate reader (BMG Labtech) equipped with a homogeneous time resolved fluorescence module with excitation at $337 \mathrm{~nm}$ and emission 620 and $655 \mathrm{~nm}$. HTRF ratios were calculated by dividing the acceptor signal $(655 \mathrm{~nm})$ by the donor signal $(620$ $\mathrm{nm})$.

Confocal Microscopy. Cell were grown to $70-80 \%$ confluence in eight-well borosilicate chambered-coverglass plates (Nunc Nalgene, Rochester, NY) precoated with poly-D-lysine $48 \mathrm{~h}$ before imaging. On the day of the experiment, medium was removed and the cells were labeled for $30 \mathrm{~min}$ at $37^{\circ} \mathrm{C}$ with $0.2 \mu \mathrm{M}$ SNAP AF488 or AF647 as required in fresh HBSS [HEPES Balanced Salt Solution (HBSS), 25 $\mathrm{mM}$ HEPES, $10 \mathrm{mM}$ glucose, $145 \mathrm{mM} \mathrm{NaCl}, 5 \mathrm{mM} \mathrm{KCl}, 1 \mathrm{mM}$ $\mathrm{MgSO}_{4}, 2 \mathrm{mM}$ sodium pyruvate, $1.3 \mathrm{mM} \mathrm{CaCl}{ }_{2}$ at $\mathrm{pH}$ 7.4]. After washing twice with HBSS, the cells were treated with or without $1 \mu \mathrm{M}$ ZM241385 for $30 \mathrm{~min}$ at $37{ }^{\circ} \mathrm{C}$. Following the incubation step, the fluorescent ligands under investigation were added to the appropriate wells at the required concentrations. Live cell imaging was performed at $37{ }^{\circ} \mathrm{C}$ using a Zeiss LSM 710 laser scanning confocal microscope fitted with a Zeiss Plan-Neofluar $40 \times 1.2 \mathrm{NA}$ water immersion objective. A $633 \mathrm{~nm}$ HeNe laser was used for the excitation of the BODIPY630/650, Cy5 and AF647 representative fluorophores, and A $488 / 561 / 633$ dichroic, and the emission was detected using $650 \mathrm{~nm}$ LP filter. A $488 \mathrm{~nm} \mathrm{HeNe}$ laser was used for BODIPY-FL fluorophores series and the emission was detected using LP575 filter. The pinhole diameter ( 1 Airy Unit; $1.1 \mu \mathrm{m}$ optical slice), laser power and gained remained constant in all the experiments. Images were processed in Zeiss Zen 2 (blue edition) software, and linear adjustments to the brightness and contrast have been applied equally across all the images.

Data Analysis. All data are represented as mean \pm SEM of $n$ experiments performed in triplicate. The $n$ refers to the number of separate experiments. A separate experiment requires cells plated from a separate flask and separate drug dilution used throughout the experiment. The data were presented and analyzed using Prism software (GraphPad Prism 7) and Excel.

Reporter Gene SPAP Assay. Antagonism by unlabeled and labeled (fluorescent) ligands of the CRE-reporter gene response (SPAP, secreted placental alkaline phosphatase) to NECA in CHO cells expressing the human $A_{2 A} A R$ was analyzed. For each concentration of the antagonists, the ratio (DR, dose ratio) of NECA concentrations required to produce the same sized response in the presence and absence of the antagonist was determined. The antagonist dissociation constant $\left(K_{\mathrm{B}}\right)$ was determined by globally fitting the data to the Schild equation:

$$
\log (\mathrm{DR}-1)=\log ([\mathrm{B}])-\log K_{\mathrm{B}}
$$

where DR (dose ratio) is the ratio of the agonist concentration required to stimulate an identical response in the presence or absence of antagonist, $[\mathrm{B}] . K_{\mathrm{B}}$ represents the equilibrium dissociation constant of the antagonist.

NanoBRET Assay. Total and nonspecific saturation binding curves were fitted simultaneously using the following equation:

$$
\text { BRET ratio }=\frac{B_{\max }[\mathrm{B}]}{[\mathrm{B}]+\left(K_{\mathrm{D}}\right)}+M[\mathrm{~B}]+C
$$

where $B_{\max }$ is the maximal response, [B] is the concentration of fluorescent ligand in $\mathrm{nM}, K_{\mathrm{D}}$ is the equilibrium dissociation constant in $\mathrm{nM}, M$ is the slope of the nonspecific binding component, and $C$ is the intercept with the $y$ axis.

The competition binding curves were fitted to the following equation:

$$
\text { uninhibited specific binding }=100-\frac{100 \times[\mathrm{A}]}{[\mathrm{A}]+\left(\mathrm{IC}_{50}\right)}
$$

where $[\mathrm{A}]$ is the concentration of competing drug and the $\mathrm{IC}_{50}$ is the molar concentration of ligand required to inhibit $50 \%$ of the specific binding of $50 \mathrm{nM}$ Alexa Fluor 647-bearing probe 17.

The Cheng-Prusoff equation was used to correct fitted $\mathrm{IC}_{50}$ values to $K_{\mathrm{i}}$ values:

$$
K_{\mathrm{i}}-\frac{\mathrm{IC}_{50}}{1+\frac{[\mathrm{L}]}{K_{\mathrm{D}}}}
$$

where $[\mathrm{L}]$ is the concentration of fluorescent ligand in $\mathrm{nM}$ and $K_{\mathrm{D}}$ is the dissociation constant of fluorescent ligand in $\mathrm{nM}$. The calculated $K_{\mathrm{D}}$ values used were as calculated from the saturation binding experiments.

HTRF Binding Kinetic Assay. From association binding kinetics, nonspecific binding was determined for each concentration of the fluorescent conjugate at each time point by adding $10 \mu \mathrm{M}$ of ZM241385, and this was subtracted from total binding to obtain specific binding measurements. The association rate $\left(k_{\mathrm{on}}\right)$ in $\mathrm{M}^{-1}$ 
$\min ^{-1}$ and dissociation rate $\left(k_{\text {off }}\right)$ in $\min ^{-1}$ constants were calculated from specific binding following equation:

$$
k_{\mathrm{on}}=\frac{k_{\mathrm{obs}}-k_{\mathrm{off}}}{[\mathrm{L}]}
$$

where [L] is the concentration of the fluorescent conjugate in $M$, and $k_{\mathrm{obs}}$ is calculated from the global fitting of the data to the following exponential association function:

$$
Y=Y_{\max }\left(1-e^{-k_{\text {obs }} t}\right.
$$

where $Y$ is the specific binding at time $t, Y_{\max }$ represents the specific binding at infinite time $(t)$, and $k_{\mathrm{obs}}$ is the rate constant for the observed rate of association.

The kinetic equilibrium dissociation constant $\left(K_{\mathrm{D}}\right)$ was determined from the data using the following equation:

$$
K_{\mathrm{D}}=\frac{k_{\text {off }}}{k_{\text {on }}}
$$

\section{ASSOCIATED CONTENT}

\section{(S) Supporting Information}

The Supporting Information is available free of charge at https://pubs.acs.org/doi/10.1021/acs.jmedchem.9b01856.

Additional pharmacological data and analytical HPLC chromatograms of the final fluorescent ligands (PDF) Molecular formula strings of tested compounds (CSV)

\section{AUTHOR INFORMATION}

\section{Corresponding Authors}

*For B.K.: phone, +44-115-9513026; fax, +44-115-9513412;

E-mail, barrie.kellam@nottingham.ac.uk.

*For S.J.H: phone, +44-115-8230082; fax, +44-115-8230081;

E-mail, stephen.hill@nottingham.ac.uk.

\section{ORCID $\odot$}

Peter J. Scammells: 0000-0003-2930-895X

Barrie Kellam: 0000-0003-0030-9908

\section{Notes}

The authors declare no competing financial interest.

\section{ACKNOWLEDGMENTS}

We acknowledge the School of Life Sciences Imaging Facility, specifically Tim Self, for assistance with the confocal microscopy. We also thank the School of Chemistry Mass Spectrometry and NMR services of the University of Nottingham. This work was supported by the Medical Research Council (grant no. MR/NO20081/1) and the Nottingham-Monash Joint Doctoral Training Center program.

\section{ABBREVIATIONS USED}

ATP, adenosine 5'-triphospate; AF647, Alexa Fluor 647; AR, adenosine receptor; BODIPY, 4,4-difluoro-4-bora-3a,4a-diaza$s$-indacene; BRET, bioluminescence resonance energy transfer; cAMP, cyclic adenosine monophosphate; CNS, central nervous system; Cy5, cyanine 5; DIPEA, diisopropylethylamine; ESI, electrospray ionization; FCS, fluorescence correlation spectroscopy; FRET, fluorescence resonance energy transfer; GPCR, G protein-coupled receptor; HATU, $O$-(7-azabenzotriazol-1-yl)-1,1,3,3-tetramethyluronium hexafluorophosphate; HEK, human embryonic kidney; HPLC, high-performance liquid chromatography; HRMS, high-resolution mass spectrometry; LC-MS, liquid chromatographymass spectrometry; NanoBRET, nanoluciferase-biolumines- cence-resonance energy transfer; NanoLuc, nanoluciferase; NMR, nuclear magnetic resonance; RP, reverse-phase; PD, Parkinson's disease; SAR, structure-activity relationship; SPAP, secreted placental alkaline phosphatase; TR-FRET, time-resolved fluorescence resonance energy transfer

\section{REFERENCES}

(1) Santos, R.; Ursu, O.; Gaulton, A.; Bento, A. P.; Donadi, R. S.; Bologa, C. G.; Karlsson, A.; Al-Lazikani, B.; Hersey, A.; Oprea, T. I.; Overington, J. P. A Comprehensive Map of Molecular Drug Targets. Nat. Rev. Drug Discovery 2017, 16 (1), 19-34.

(2) Fredholm, B. B.; Arslan, G.; Halldner, L.; Kull, B.; Schulte, G.; Wasserman, W. Structure and Function of Adenosine Receptors and Their Genes. Naunyn-Schmiedeberg's Arch. Pharmacol. 2000, 362 (45), 364-374.

(3) de Lera Ruiz, M.; Lim, Y.; Zheng, J. Adenosine A2A Receptor as a Drug Discovery Target. J. Med. Chem. 2014, 57, 3623-3650.

(4) Müller, C. E.; Jacobson, K. A. Recent Developments in Adenosine Receptor Ligands and Their Potential as Novel Drugs. Biochim. Biophys. Acta, Biomembr. 2011, 1808 (5), 1290-1308.

(5) Kull, B.; Svenningsson, P.; Fredholm, B. B. Adenosine A(2A) Receptors Are Colocalized with and Activate $\mathrm{g}(\mathrm{Olf})$ in Rat Striatum. Mol. Pharmacol. 2000, 58 (4), 771-777.

(6) Fredholm, B. B.; IJzerman, A. P.; Jacobson, K. A.; Klotz, K. N.; Linden, J. International Union of Pharmacology. XXV. Nomenclature and Classification of Adenosine Receptors. Pharmacol. Rev. 2001, 53, 527-552.

(7) Jaakola, V. P.; Griffith, M. T.; Hanson, M. A.; Cherezov, V.; Chien, E. Y.; Lane, J. R.; Ijzerman, A. P.; Stevens, R. C. The 2.6 Angstrom Crystal Structure of a Human $\mathrm{A}_{2 \mathrm{~A}}$ Adenosine Receptor Bound to an Antagonist. Science 2008, 322 (2), 1211-1218.

(8) Xu, F.; Wu, H.; Katritch, V.; Han, G. W.; Jacobson, K. A.; Gao, Z.-G.; Cherezov, V.; Stevens, R. C. Structure of an Agonist-Bound Human $\mathrm{A}_{2 \mathrm{~A}}$ Adenosine Receptor. Science 2011, 332 (6027), 322-327.

(9) Liu, W.; Chun, E.; Thompson, A. A.; Chubukov, P.; Xu, F.; Katritch, V.; Han, G. W.; Roth, C. B.; Heitman, L. H.; IJzerman, A. P.; Cherezov, V.; Stevens, R. C. Structural Basis for Allosteric Regulation of GPCRs by Sodium Ions. Science 2012, 337 (6091), 232-236.

(10) Langmead, C. J.; Andrews, S. P.; Congreve, M.; Errey, J. C.; Hurrell, E.; Marshall, F. H.; Mason, J. S.; Richardson, C. M.; Robertson, N.; Zhukov, A.; Weir, M. Identification of Novel Adenosine $\mathrm{A}_{2 \mathrm{~A}}$ Receptor Antagonists by Virtual Screening. J. Med. Chem. 2012, 55 (5), 1904-1909.

(11) Congreve, M.; Andrews, S. P.; Doré, A. S.; Hollenstein, K.; Hurrell, E.; Langmead, C. J.; Mason, J. S.; Ng, I. W.; Tehan, B.; Zhukov, A.; Weir, M.; Marshall, F. H. Discovery of 1,2,4-Triazine Derivatives as Adenosine A2Aantagonists Using Structure Based Drug Design. J. Med. Chem. 2012, 55 (5), 1898-1903.

(12) Jacobson, K. A.; Gao, Z.-G. Adenosine Receptors as Therapeutic Targets. Nat. Rev. Drug Discovery 2006, 5, 247-264.

(13) Chen, J.-F.; Eltzschig, H. K.; Fredholm, B. B. Adenosine Receptors as Drug Targets - What Are the Challenges? Nat. Rev. Drug Discovery 2013, 12 (4), 265-286.

(14) Burnstock, G. Purinergic Signalling and Disorders of the Central Nervous System. Nat. Rev. Drug Discovery 2008, 7 (7), 575590.

(15) Antonioli, L.; Blandizzi, C.; Pacher, P.; Haskó, G. Immunity, Inflammation and Cancer: A Leading Role for Adenosine. Nat. Rev. Cancer 2013, 13 (12), 842-857.

(16) Ohta, A.; Gorelik, E.; Prasad, S. J.; Ronchese, F.; Lukashev, D.; Wong, M. K. K.; Huang, X.; Caldwell, S.; Liu, K.; Smith, P.; Chen, J.F.; Jackson, E. K.; Apasov, S.; Abrams, S.; Sitkovsky, M. A $A_{2 A}$ Adenosine Receptor Protects Tumors from Antitumor $\mathrm{T}$ Cells. Proc. Natl. Acad. Sci. U. S. A. 2006, 103 (35), 13132-13137.

(17) Ohta, A. A Metabolic Immune Checkpoint: Adenosine in Tumor Microenvironment. Front. Immunol. 2016, 7, 109.

(18) Inoue, Y.; Yoshimura, K.; Kurabe, N.; Kahyo, T.; Kawase, A.; Tanahashi, M.; Ogawa, H.; Inui, N.; Funai, K.; Shinmura, K.; Niwa, 
H.; Suda, T.; Sugimura, H. Prognostic Impact of CD73 and A2A Adenosine Receptor Expression in Non-Small-Cell Lung Cancer. Oncotarget 2017, 8, 8738-8751.

(19) Al Jaroudi, W.; Iskandrian, A. E. Regadenoson: A New Myocardial Stress Agent. J. Am. Coll. Cardiol. 2009, 54 (13), 11231130.

(20) Dungo, R.; Deeks, E. D. Istradefylline: First Global Approval. Drugs 2013, 73 (8), 875-882.

(21) FDA Approves New Add-On Drug to Treat off Episodes in Adults with Parkinson's Disease; U.S. Food and Drug Administration, August 27, 2019; https://www.fda.gov/news-events/press-announcements/ fda-approves-new-add-drug-treat-episodes-adults-parkinsons-disease.

(22) Arruda, M. A.; Stoddart, L. A.; Gherbi, K.; Briddon, S. J.; Kellam, B.; Hill, S. J. A Non-Imaging High Throughput Approach to Chemical Library Screening at the Unmodified Adenosine- $\mathrm{A}_{3}$ Receptor in Living Cells. Front. Pharmacol. 2017, 8, 908.

(23) Vernall, A. J.; Stoddart, L. A.; Briddon, S. J.; Hill, S. J.; Kellam, B. Highly Potent and Selective Fluorescent Antagonists of the Human Adenosine A3 Receptor Based on the 1,2,4-Triazolo[4,3-a]Quinoxalin- 1-One Scaffold. J. Med. Chem. 2012, 55 (4), 1771-1782. (24) Stoddart, L. A.; Vernall, A. J.; Briddon, S. J.; Kellam, B.; Hill, S. J. Direct Visualisation of Internalization of the Adenosine A3 Receptor and Localization with Arrestin3 Using a Fluorescent Agonist. Neuropharmacology 2015, 98, 68-77.

(25) Middleton, R. J.; Briddon, S. J.; Cordeaux, Y.; Yates, A. S.; Dale, C. L.; George, M. W.; Baker, J. G.; Hill, S. J.; Kellam, B. New Fluorescent Adenosine $\mathrm{A}_{1}$-Receptor Agonists That Allow Quantification of Ligand - Receptor Interactions in Microdomains of Single Living Cells. J. Med. Chem. 2007, 50 (4), 782-793.

(26) Briddon, S. J.; Middleton, R. J.; Cordeaux, Y.; Flavin, F. M.; Weinstein, J. A.; George, M. W.; Kellam, B.; Hill, S. J. Quantitative Analysis of the Formation and Diffusion of A1-Adenosine Receptor Antagonist Complexes in Single Living Cells. Proc. Natl. Acad. Sci. U. S. A. 2004, 101 (13), 4673-4678.

(27) Kecskés, M.; Kumar, T. S.; Yoo, L.; Gao, Z. G.; Jacobson, K. A. Novel Alexa Fluor-488 Labeled Antagonist of the A2A Adenosine Receptor: Application to a Fluorescence Polarization-Based Receptor Binding Assay. Biochem. Pharmacol. 2010, 80 (4), 506-511.

(28) Duroux, R.; Ciancetta, A.; Mannes, P.; Yu, J.; Boyapati, S.; Gizewski, E.; Yous, S.; Ciruela, F.; Auchampach, J. A.; Gao, Z.-G.; Jacobson, K. A. Bitopic Fluorescent Antagonists of the $A_{2 A}$ Adenosine Receptor Based on Pyrazolo[4,3-e][1,2,4]Triazolo[1,5-c]Pyrimidin-5Amine Functionalized Congeners. MedChemComm 2017, 8 (8), $1659-1667$.

(29) Neustadt, B. R.; Hao, J.; Lindo, N.; Greenlee, W. J.; Stamford, A. W.; Tulshian, D.; Ongini, E.; Hunter, J.; Monopoli, A.; Bertorelli, R.; Foster, C.; Arik, L.; Lachowicz, J.; Ng, K.; Feng, K. I. Potent, Selective, and Orally Active Adenosine A2Areceptor Antagonists: Arylpiperazine Derivatives of Pyrazolo[4,3-e]-1,2,4-Triazolo[1,5-c]Pyrimidines. Bioorg. Med. Chem. Lett. 2007, 17 (5), 1376-1380.

(30) Shinkre, B. A.; Kumar, T. S.; Gao, Z. G.; Deflorian, F.; Jacobson, K. A.; Trenkle, W. C. Synthesis and Evaluation of 1,2,4Triazolo[1,5-c] Pyrimidine Derivatives as $A_{2 A}$ Receptor-Selective Antagonists. Bioorg. Med. Chem. Lett. 2010, 20 (19), 5690-5694.

(31) Basu, S.; Barawkar, D. A.; Ramdas, V.; Naykodi, M.; Shejul, Y. D.; Patel, M.; Thorat, S.; Panmand, A.; Kashinath, K.; Bonagiri, R.; Prasad, V.; Bhat, G.; Quraishi, A.; Chaudhary, S.; Magdum, A.; Meru, A. V.; Ghosh, I.; Bhamidipati, R. K.; Raje, A. A.; Madgula, V. L. M.; De, S.; Rouduri, S. R.; Palle, V. P.; Chugh, A.; Hariharan, N.; Mookhtiar, K. A. Discovery of Potent and Selective $A_{2 A}$ Antagonists with Efficacy in Animal Models of Parkinson's Disease and Depression. ACS Med. Chem. Lett. 2017, 8 (8), 835-840.

(32) Carlsson, J.; Yoo, L.; Gao, Z.-G.; Irwin, J. J.; Shoichet, B. K.; Jacobson, K. A. Structure-Based Discovery of $\mathrm{A}_{2 \mathrm{~A}}$ Adenosine Receptor Ligands. J. Med. Chem. 2010, 53 (9), 3748-3755.

(33) Baraldi, S.; Baraldi, P. G.; Oliva, P.; Toti, K. S.; Ciancetta, A.; Jacobson, K. A. $\mathrm{A}_{2 \mathrm{~A}}$ Adenosine Receptor : Structures, Modeling, and Medicinal Chemistry. Adenosine Receptors. 2018, 34, 91-136.
(34) Baker, J. G.; Middleton, R.; Adams, L.; May, L. T.; Briddon, S. J.; Kellam, B.; Hill, S. J. Influence of Fluorophore and Linker Composition on the Pharmacology of Fluorescent Adenosine $A_{1}$ Receptor Ligands: Themed Section: Imaging in Pharmacology Research Paper. Br. J. Pharmacol. 2010, 159 (4), 772-786.

(35) Vernall, A. J.; Stoddart, L. A.; Briddon, S. J.; Ng, H. W.; Laughton, C. A.; Doughty, S. W.; Hill, S. J.; Kellam, B. Conversion of a Non-Selective Adenosine Receptor Antagonist into $\mathrm{A}_{3}$-Selective High Affinity Fluorescent Probes Using Peptide-Based Linkers. Org. Biomol. Chem. 2013, 11 (34), 5673.

(36) Stoddart, L. A.; Vernall, A. J.; Bouzo-Lorenzo, M.; Bosma, R.; Kooistra, A. J.; De Graaf, C.; Vischer, H. F.; Leurs, R.; Briddon, S. J.; Kellam, B.; Hill, S. J. Development of Novel Fluorescent Histamine H1-Receptor Antagonists to Study Ligand-Binding Kinetics in Living Cells. Sci. Rep. 2018, 8, 1572.

(37) Conroy, S.; Kindon, N. D.; Glenn, J.; Stoddart, L. A.; Lewis, R. J.; Hill, S. J.; Kellam, B.; Stocks, M. J. Synthesis and Evaluation of the First Fluorescent Antagonists of the Human P2Y Receptor Based on AR-C118925. J. Med. Chem. 2018, 61 (7), 3089-3113.

(38) Schembri, L. S.; Stoddart, L. A.; Briddon, S. J.; Kellam, B.; Canals, M.; Graham, B.; Scammells, P. J. Synthesis, Biological Evaluation, and Utility of Fluorescent Ligands Targeting the $\mu$-Opioid Receptor. J. Med. Chem. 2015, 58 (24), 9754-9767.

(39) Ulrich, G.; Ziessel, R.; Harriman, A. The Chemistry of Fluorescent Bodipy Dyes: Versatility Unsurpassed. Angew. Chem., Int. Ed. 2008, 47 (7), 1184-1201.

(40) Alcobia, D. C.; Ziegler, A. I.; Kondrashov, A.; Comeo, E.; Mistry, S.; Kellam, B.; Chang, A.; Woolard, J.; Hill, S. J.; Sloan, E. K. Visualising Ligand-Binding to a GPCR in Vivo Using NanoBRET. iScience 2018, 6, 280-288.

(41) Saccomano, M.; Dullin, C.; Alves, F.; Napp, J. Preclinical Evaluation of Near-Infrared (NIR) Fluorescently Labeled Cetuximab as a Potential Tool for Fluorescence-Guided Surgery. Int. J. Cancer 2016, 139 (10), 2277-2289.

(42) Kuo, S.-C.; Tran, T.; Zhang, P. Process for preparing substituted 5-amino-pyrazolo-[4,3-e]-1,2,4-triazolo[1,5-c]pyrimidine. U.S. Patent US7,235,659, Jun 26, 2007.

(43) Klötzer, W.; Herberz, M. Chlorierende Formylierungsreaktionen an Pyrimidinen Die Reaktion Des Formylierungsreagens Mit Einer Am Pyrimidinkern. Monatsh. Chem. 1965, 96 (5), 1567-1572.

(44) Ashry, E.S.H.E.; Kilany, Y.E.; Rashed, N.; Assafir, H. Dimroth Rearrangement: Translocation of Heteroatoms in Heterocyclic Rings and Its Role in Ring Transformations of Heterocycles. Adv. Heterocycl. Chem. 1999, 75, 79-165.

(45) Dale, C. L.; Hill, S. J.; Kellam, B. New Potent, Short-Linker BODIPY-630/650 Labelled Fluorescent Adenosine Receptor Agonists. MedChem Comm 2012, 3, 333-338.

(46) Stoddart, L. A.; Kilpatrick, L. E.; Hill, S. J. NanoBRET Approaches to Study Ligand Binding to GPCRs and RTKs. Trends Pharmacol. Sci. 2018, 39 (2), 136-147.

(47) Dale, N. C.; Johnstone, E. K. M.; White, C. W.; Pfleger, K. D. G. NanoBRET: The Bright Future of Proximity-Based Assays. Front. Bioeng. Biotechnol. 2019, 7, 56.

(48) Hall, M. P.; Unch, J.; Binkowski, B. F.; Valley, M. P.; Butler, B. L.; Wood, M. G.; Otto, P.; Zimmerman, K.; Vidugiris, G.; Machleidt, T.; Robers, M. B.; Benink, H. A.; Eggers, C. T.; Slater, M. R.; Meisenheimer, P. L.; Klaubert, D. H.; Fan, F.; Encell, L. P.; Wood, K. V. Engineered Luciferase Reporter from a Deep Sea Shrimp Utilizing a Novel Imidazopyrazinone Substrate. ACS Chem. Biol. 2012, 7 (11), $1848-1857$.

(49) Machleidt, T.; Woodroofe, C. C.; Schwinn, M. K.; Méndez, J.; Robers, M. B.; Zimmerman, K.; Otto, P.; Daniels, D. L.; Kirkland, T. A.; Wood, K. V. NanoBRET-A Novel BRET Platform for the Analysis of Protein-Protein Interactions. ACS Chem. Biol. 2015, 10 (8), 17971804.

(50) Hill, S. J.; Baker, J. G.; Rees, S. Reporter-Gene Systems for the Study of G-Protein-Coupled Receptors. Curr. Opin. Pharmacol. 2001, 1 (5), 526-532. 
(51) Christopoulos, A.; Kenakin, T. G Protein-Coupled Receptor Allosterism and Complexing. Pharmacol. Rev. 2002, 54 (2), 323-374.

(52) Sykes, D. A.; Stoddart, L. A.; Kilpatrick, L. E.; Hill, S. J. Binding Kinetics of Ligands Acting at GPCRs. Mol. Cell. Endocrinol. 2019, 485, 9-19.

(53) Copeland, R. A.; Pompliano, D. L.; Meek, T. D. Drug - Target Residence Time and Its Implications for Lead Optimization. Nat. Rev. Drug Discovery 2006, 5, 730-740.

(54) Guo, D.; Heitman, L. H.; Ijzerman, A. P. Kinetic Aspects of the Interaction between Ligand and $\mathrm{g}$ Proteincoupled Receptor: The Case of the Adenosine Receptors. Chem. Rev. 2017, 117 (1), 38-66.

(55) Stoddart, L. A.; Kilpatrick, L. E.; Briddon, S. J.; Hill, S. J. Probing the Pharmacology of G Protein-Coupled Receptors with Fluorescent Ligands. Neuropharmacology 2015, 98, 48-57.

(56) Stoddart, L. A.; White, C. W.; Nguyen, K.; Hill, S. J.; Pfleger, K. D. G. Fluorescence- and Bioluminescence-Based Approaches to Study GPCR Ligand Binding. Br. J. Pharmacol. 2016, 173 (20), 3028-3037. (57) Sykes, D. A.; Moore, H.; Stott, L.; Holliday, N.; Javitch, J. A.; Lane, J. R.; Charlton, S. J. Extrapyramidal Side Effects of Antipsychotics Are Linked to Their Association Kinetics at Dopamine D2 Receptors. Nat. Commun. 2017, 8, 763.

(58) Cottet, M.; Faklaris, O.; Maurel, D.; Scholler, P.; Doumazane, E.; Trinquet, E.; Pin, J. P.; Durroux, T. BRET and Time-Resolved FRET Strategy to Study GPCR Oligomerization: From Cell Lines toward Native Tissues. Front. Endocrinol. 2012, 3, 92.

(59) Fredholm, B. B.; IJzerman, A. P.; Jacobson, K. A.; Linden, J.; Müller, C. E. International Union of Pharmacology. LXXXI. Nomenclature and Classification of Adenosine Receptors-An Update. Pharmacol. Rev. 2011, 63 (1), 1-34.

(60) Ongini, E.; Dionisotti, S.; Gessi, S.; Irenius, E.; Fredholm, B. B. Comparison of CGS 15943, ZM 241385 and SCH 58261 as Antagonists at Human Adenosine Receptors. Naunyn-Schmiedeberg's Arch. Pharmacol. 1999, 359 (1), 7-10.

(61) Bunnage, M. E.; Chekler, E. L. P.; Jones, L. H. Target Validation Using Chemical Probes. Nat. Chem. Biol. 2013, 9 (4), 195-199.

(62) Simon, G. M.; Niphakis, M. J.; Cravatt, B. F. Determining Target Engagement in Living Systems. Nat. Chem. Biol. 2013, 9 (4), 200-205.

(63) Stoddart, L. A.; Johnstone, E. K. M.; Wheal, A. J.; Goulding, J.; Robers, M. B.; MacHleidt, T.; Wood, K. V.; Hill, S. J.; Pfleger, K. D. G. Application of BRET to Monitor Ligand Binding to GPCRs. Nat. Methods 2015, 12 (7), 661-663. 